EISSN: $2706-7947$ ISSN: 2077- 4613

DOI: 10.36632/mejas/2021.11.1.9

Journal homepage: www.curresweb.com

Pages: 126-142

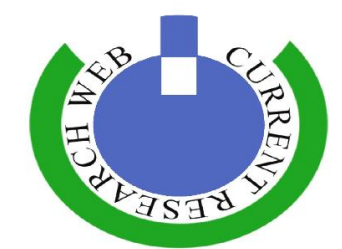

\title{
Effect of Adding Magnetic Iron and Fertilizer Rates on Vegetative Growth, Yield, Quality and Storability of Cucumber
}

\author{
Sheren A. Atala ${ }^{1}$, S. Abou-El-Hassan ${ }^{2}$, F.A. Hashem ${ }^{3}$ and Manal M.H. Gad El-Moula ${ }^{3}$ \\ ${ }^{I}$ Department of Postharvest and Handling of Vegetable Crops, Horticulture Research Institute, \\ Agricultural Research Center, Giza, Egypt. \\ ${ }^{2}$ Central Lab of Organic Agriculture, Agricultural Research Center, Egypt. \\ ${ }^{3}$ Central Laboratory for Agricultural Climate, Agricultural Research Center, Egypt.
}

Received: 30 November 2020 Accepted: 30 January $2021 \quad$ Published: 15 February 2021

\begin{abstract}
Reducing the use of mineral fertilizers with maximizing their efficiency is a requirement of great importance for world agricultural production and leads to preserving the environment and reducing greenhouse gas emissions (GHG), which will reduce the impacts of climate change on the agricultural sector. This experiment was performed to evaluate the efficacy of magnetic iron under different rates of mineral fertilizer on the production, fruit quality and storability of cucumber. The experiment was carried out in the experimental farm of Dokki site for Protected Agriculture, Ministry of Agriculture and Land Reclamation and Laboratory of Handling of Vegetable Department, Horticulture Research Institute, Giza, Egypt, during two successive seasons of 2018/2019 and 2019/2020. Three rates of recommended mineral fertilizer (100, 75 and 50\%) of NPK with and without adding magnetic iron (soil addition at rate $5 \mathrm{~g} / \mathrm{plant}$ ), were applied on cucumber (Gianco $\mathrm{F}_{1}$ ). All vegetative growth properties, nutritional status of plants, yield and properties of cucumber fruits were improved significantly by increasing mineral fertilizer rate to $100 \%$. The plants treated with magnetic iron recorded a significant increment in growth, NPK content of plants, yield and properties of cucumber fruits compared to untreated plants. The highest yield was produced by using $100 \%$ mineral fertilizer with adding magnetic iron. Noteworthy, application of $75 \%$ mineral fertilizer with adding magnetic iron had achieved yield and fruit quality higher than using $100 \%$ mineral fertilizer without adding magnetic iron. The highest nutrient use efficiency was true using magnetic iron with 50\% mineral fertilizer. The treatments of 100 and $75 \%$ mineral fertilizer with adding magnetic iron improved the storability of cucumber fruits (reduced weight loss and color change; maintained fruit firmness, TSS and ascorbic acid content) and exhibited good appearance till 16 days of storage at $10^{\circ} \mathrm{C}$ plus two days at $15^{\circ} \mathrm{C}$ as a shelf life compared to using $100 \%$ mineral fertilizer without adding magnetic iron which had less effect in this concern.
\end{abstract}

Keywords: Cucumber, Magnetic iron, Fertilizer rates, Quality, Storability, Nutrient use efficiency

\section{Introduction}

Cucumber (Cucumis sativusL.) considers one of the most important vegetable crops that belong to the family Cucurbitaceae, it cultivated either in open field or under protected cultivation at all over the world. Nowadays, Egypt has a great potential for greenhouse and the area has rapidly increased through the last few years. Cucumber was ranked the first order as cash and commercial crop of vegetables grown under the greenhouse for local market. Total number of greenhouses estimated at 51663 units with an area of 4413 feddans (feddan $=0.42$ hectare), of which 25787 planted with cucumber plants with an area of 2132 feddans, with an average productivity of $11.16 \mathrm{~kg} / \mathrm{m}^{2}$ according to statistics of Ministry of Agriculture and Land Reclamation (2017).

Corresponding Author: Sheren A. Atala, Department of Postharvest and Handling of Vegetable Crops, Horticulture Research Institute, Agricultural Research Center, Giza, Egypt. 
The magnetite (magnetic iron) is one of natural row rocks naturally magnetic in the world that has a black or brownish-red (Mansour, 2007). The addition of the natural magnetic iron could enhances soil structure, organic matter, water properties, cation exchange capacity and become more energy known as "Magneto biology", which helps to moderate the soil temperature, improve water hold capacity and crop nutrition from macro and micronutrients. Moreover, the magnetic process separates chlorine and harmful gases from soil, which increases salt movement and nutrient solubility (Ismail et al., 2010). Using magnetic iron as a natural soil improvement products, where it played an important role in cation uptake capacity and had a positive effect on immobile plant nutrient uptake (Esitken and Turan, 2004; Mansour, 2007). Indeed, several studies demonstrated that application of magnetic iron increased vegetative growth and yield of different crops such as cauliflower (El-Hifny et al., 2008), pepper (Ali et al., 2011; Taha et al., 2011), cucumber (Shehata et al., 2012) and cantaloupe (ElEslamboly and Abdel-Wahab, 2014). Moreover, some studies indicated that, magnetic field had a benefit effect on plant nutrition and yield, Esitken and Turan (2004) on strawberry, Podlesny et al. (2005) on pea, Shahin et al. (2016) on cucumber; as well as increased yield and quality of potato (ElGizawy et al., 2016). El-Zawily et al. (2018) Showed that cucumber plants treated with magnetite or magnetized water treatments produced the highest values of vegetative growth parameters, i.e., plant height, number of internodes, number of leaves, number branches, leaf area index, early and total fruit yield (weight and number), fruit quality, soluble solids content and firmness and leaves chemical content; total green color reading (SPAD), N, P and K compared to non-treated plants which had the lowest values.

Fertilizer is a major part of the expenses for cucumber production, where fertilizer requirements of cucumber are quite high due to its high yielding during short time, especially under greenhouse. Accordingly, nutrition with suitable levels of N, P and $\mathrm{K}$ had a key role for promoting the growth and yield of cucumber (Salisbury and Ross, 1991; Marschner, 1995; Jilani et al., 2009; Eifediyi and Remison, 2010; Feleafel et al., 2014; Naik et al., 2019). However, the excessive use of N, P and K fertilizers create pollution of agro-ecosystem through pollution the groundwater with nitrate and increasing nitrate content in agricultural products, causing hazardous effects on human health, as well as reduced soil fertility and microorganism activity (Mahdi et al., 2010). In addition, plants do not absorb all the mineral fertilizers that added to the soil yearly. About $50 \%$ of these fertilizers are lost by volatilization in the atmosphere or leaching into the soil, causing increment of greenhouse gases, pollution of groundwater and salinization of soil (Simpson et al., 2011).

The agriculture, forestry, and other land use (AFOLU) sector contributed $14.9 \%(48,390 \mathrm{Gg}$ $\mathrm{CO}_{2} \mathrm{e}$ ) of national GHG emissions in 2015. The largest contributor to the total GHG emissions is use of chemical fertilizers (66\%) followed by livestock (34\%) (Egypt's first Biennial Update Report 2018). Using lower doses of chemical fertilizers gives low emissions of $\mathrm{N}_{2} \mathrm{O}$ and $\mathrm{CO}_{2}$ emissions. $\mathrm{N}_{2} \mathrm{O}$ is an important GHG that contributes to climate change. Because it has a long atmospheric lifetime (over 100 years) and is about 300 times better at trapping heat than $\mathrm{CO}_{2}$, even small emissions of $\mathrm{N}_{2} \mathrm{O}$ affect the climate. Consequently, improving the management of mineral fertilizer for crops can improve nutrient use efficiency (saving farmers money) and reduce GHG emission (enhancing the climate), (Farag and Abd-Elrahman, 2016)

Therefore, the present research aims to study the possibility of utilizing magnetic iron to reduce the rates of mineral fertilizer for reducing the production costs without harming the environment or the human's health, as well as its effect on production, quality and storability of cucumber fruits.

\section{Materials and Methods}

The experiment was carried out on cucumber under a greenhouse of white nets $(30 \mathrm{~m}$ length and $8.5 \mathrm{~m}$ width) at the experimental farm of Dokki site for Protected Agriculture, Ministry of Agriculture and Land Reclamation, Giza, Egypt, during two successive seasons of 2018/2019 and 2019/2020.

\subsection{Plant Material}

Seeds of cucumber (Gianco $F_{1}$ ) were sown on $14^{\text {th }}$ and $18^{\text {th }}$ of September in the first and second seasons, respectively. The physical and chemical properties of the soil are tabulated in Table 1. 
Table 1: Analyses of the experimental soil

\begin{tabular}{|c|c|c|c|c|c|c|c|c|c|c|c|c|}
\hline \multirow{2}{*}{$\begin{array}{l}\text { Clay } \\
(\%)\end{array}$} & \multirow{2}{*}{$\begin{array}{l}\text { Silt } \\
\text { (\%) }\end{array}$} & \multirow{2}{*}{$\begin{array}{c}\text { Sand } \\
(\%)\end{array}$} & \multirow{2}{*}{ Texture } & \multirow{2}{*}{ pH } & \multirow{2}{*}{$\begin{array}{c}\text { EC } \\
\mathrm{dS} / \mathrm{m}\end{array}$} & \multicolumn{4}{|c|}{ Cations meq/l } & \multicolumn{3}{|c|}{ Anions meq/l } \\
\hline & & & & & & $\mathbf{C a}^{++}$ & $\mathbf{M g}^{++}$ & $\mathrm{Na}^{+}$ & $\mathbf{K}^{+}$ & $\mathrm{HCO}_{3}{ }^{-}$ & $\mathrm{Cl}^{-}$ & $\mathrm{SO}_{4}{ }^{=}$ \\
\hline 48.2 & 42.3 & 8.5 & Clay silt & 8.25 & 1.26 & 2.80 & 1.55 & 6.34 & 1.18 & 2.44 & 5.46 & 3.58 \\
\hline
\end{tabular}

\subsection{The Experimental Layout}

The experiment area was divided into ridges ( $90 \mathrm{~cm}$ width). The seeds were sown at a space of 50 $\mathrm{cm}$ in double rows on the ridge. Air temperature and relative humidity (RH \%) were recorded under experiment conditions by a digital meteorological station during both growing seasons and were shown in Table 2.

Table 2: Average air temperature and relative humidity during growing seasons

\begin{tabular}{|c|c|c|c|c|c|c|}
\hline \multirow[b]{3}{*}{ Months } & \multicolumn{3}{|c|}{ First season $(2018 / 2019)$} & \multicolumn{3}{|c|}{ Second season $(2019 / 2020)$} \\
\hline & \multicolumn{2}{|c|}{ Air temperature } & \multirow{2}{*}{$\begin{array}{l}\text { RH } \\
(\%)\end{array}$} & \multicolumn{2}{|c|}{ Air temperature } & \multirow{2}{*}{$\begin{array}{l}\text { RH } \\
(\%)\end{array}$} \\
\hline & Max. ${ }^{\circ} \mathrm{C}$ & $\operatorname{Min}{ }^{\circ} \mathrm{C}$ & & Max. ${ }^{\circ} \mathrm{C}$ & $\operatorname{Min}{ }^{\circ} \mathrm{C}$ & \\
\hline Spt. & 37.7 & 23.3 & 64.8 & 38.6 & 22.5 & 68.7 \\
\hline Oct. & 35.4 & 21.0 & 63.3 & 36.8 & 20.4 & 62.8 \\
\hline Nov. & 31.5 & 15.1 & 68.6 & 33.4 & 15.9 & 66.7 \\
\hline Dec. & 25.8 & 8.3 & 71.7 & 25.6 & 11.7 & 69.5 \\
\hline Jan. & 24.8 & 4.3 & 61.5 & 23.5 & 4.7 & 62.0 \\
\hline
\end{tabular}

\subsection{Experimental Design}

The experiments were arranged in split plot design with three replicates, three mineral fertilizer rates $(100,75$ and $50 \%)$ of recommended NPK were adapted in the main plots and two treatments of magnetic iron (without and with magnetic iron), were randomized in the sub plots. The plot area was $4.5 \mathrm{~m}^{2}$ (5 m length and $0.9 \mathrm{~m}$ width). The recommended mineral fertilizer of NPK was at the rate of 22 $\mathrm{kg} \mathrm{N}, 9 \mathrm{~kg} \mathrm{P}_{2} \mathrm{O}_{5}$ and $25 \mathrm{~kg} \mathrm{~K}_{2} \mathrm{O} / 1000 \mathrm{~m}^{2}$ according to Shehata et al. (2016). These fertilizers were provided using a multi fertilizer (20:9:20) at rate $125 \mathrm{~g} / \mathrm{m}^{2}$. The fertilizer was injected within drip irrigation system twice weekly. Magnetite (magnetic iron, $\mathrm{Fe}_{3} \mathrm{O}_{4}$ ) was applied as soil addition at rate $5 \mathrm{~g} / \mathrm{plant}$ before sowing the seeds. Other agricultural practices were done as recommendations of Agricultural Ministry.

\subsection{Data Recorded}

\subsubsection{Growth and nutrient content}

After 50 days from sowing, five plants were randomly taken from each plot to measure plant height, leaf number, stem diameter and shoot fresh weight of plant. In addition, chlorophyll reading was measured in the fourth upper leaf using Minolta Chlorophyll Meter Spad 501. Nutrient content (NPK) in cucumber plants were determined in the fourth upper leaf according to the procedure described by FAO (2008). Total nitrogen was determined by Kjeldahl method, phosphorus was determined using Spectrophotometer and potassium was determined photo-metrically using Flame photometer.

\subsubsection{Yield and its components}

After 55 days from sowing, the cucumber fruits were harvested twice weekly. Total yield was recorded per plot after each harvesting accumulatively until the end of harvesting season; total yield $/ \mathrm{m}^{2}$ was calculated from plot yield. Five plants from each replicate were randomly chosen to measure number of fruits per plant.

\subsubsection{Fruit quality}

A random sample of 30 fruits from each replicate was taken at harvest and the following characters were measured: fruit weight, fruit length, fruit diameter, fruit firmness, total soluble solids and ascorbic acid content.

\subsubsection{Evaluation of nutrient use efficiency}

Nutrient use efficiency (NUE) was calculated according to Jisha Chand (2014) using the following equation: 


$$
\mathrm{NUE}=\frac{\text { Yield }\left(\mathrm{kg} / \mathrm{m}^{2}\right)}{\text { Nutrient applied }\left(\mathrm{kg} / \mathrm{m}^{2}\right)}
$$

\subsection{Storage experiment}

Fruits of cucumber for each treatment were harvested at the proper stage of maturity on $11^{\text {th }}$ and $13^{\text {th }}$ of November in the first and second seasons, respectively, and then transferred to laboratory of Handling of Vegetable Crops Department, Horticultural Research Institute at Giza. Fruits were selected to their size uniformity (12-14 cm in length and $2-3 \mathrm{~cm}$ in diameter) and free of visual damage defects. All samples for pre-harvest treatments of cucumber fruits were placed in polypropylene bags $(25 \times 30$ $\mathrm{cm}$ ) and $30 \mu \mathrm{m}$ thickness. Each bag contains 6 fruits represented as experimental unit (EU). Fifteen EU were prepared for each treatment and stored at $10^{\circ} \mathrm{C}$ and $95 \%$ relative humidity (RH). Samples were taken randomly in three replicates from each EU and were arranged in complete randomized design. Measurements were examined immediately after harvest and at 4 days intervals $(0,4,8,12$ and 16 days) of storage at $10^{\circ} \mathrm{C}$ in addition to 2 days at $15^{\circ} \mathrm{C}$ as a shelf life for the following characteristics:

- Weight loss percentage was estimated according to the following equation:

$$
\boldsymbol{W L}(\%)=\frac{\boldsymbol{W} \boldsymbol{F}_{\text {Init }}-\boldsymbol{W} \boldsymbol{F}_{\text {Samp }}}{\boldsymbol{W} \boldsymbol{F}_{\text {Init }} \times 100} \times 100
$$

Where, $\mathrm{WL}$ is the percentage of weight loss, $\mathrm{WF}_{\text {Init }}$ is the initial weight of fruits, $\mathrm{WF}_{\text {Samp }}$ if the weight of fruits at sampling dates.

- General appearance was measured on score rating from 9 to 1 , where $9=$ excellent, $7=\operatorname{good}, 5=$ fair, $3=$ poor and $1=$ unsalable.

- External surface color was measured on two sides of each fruit by using a color meter (Minolta CR $200)$ to measure the lightness (L value) and hue angle $\left(\mathrm{h}^{\circ}\right)$ value (McGuire, 1992).

- Fruit firmness was measured by a hand pressure tester (Italian model) expressed in $\mathrm{kg} / \mathrm{cm}^{2}$.

-Total soluble solids percentage (TSS) was determined by using refractometer according to A.O.A.C. (2000).

-Ascorbic acid content (mg /100 g fruit fresh weight) was determined by titration method using 2, 6 dichloro-phenole-endo-phenole (A.O.A.C., 2000).

\subsection{Statistical analysis}

Data of the two seasons were arranged and statistically analyzed by the analysis of variances according to Snedecor and Cochran (1980) with SAS software, version 2004. Treatment means was compared by Tukey test at significance level 0.05 .

\section{Results and Discussion}

\subsection{Vegetative properties}

Data in Table 3 show the effect of mineral fertilizer rates and magnetic iron addition on vegetative growth properties of cucumber plants. In both seasons, values of all vegetative growth properties increased significantly as the rate of mineral fertilizer increased. The positive effect of increasing fertilizer rate up to $100 \%$ on vegetative growth properties can be explained by its contribution to several metabolic processes in plants related to promote the growth (Marschner, 1995). Moreover, to their role in increasing activity of meristemic and its importance in the metabolism of many constituents such as chlolophyll, amino acids, enzymes and protein synthesis (Salisbury and Ross, 1991), consequently stimulate the vegetative growth through prompt the plants to generate more number of leaves. These results are in accordance with those obtained by Jilani et al.(2009), where they found that increasing N, $\mathrm{P}$ and $\mathrm{K}$ rates had an important role in enhancing the vegetative growth of cucumber plant.

Treatment of magnetic iron increased all vegetative parameters of plants compared to nonmagnetic iron treatment. The superiority of growth parameters with magnetic iron addition could be attributed to magnetic iron plays an important role in cation uptake capacity and had a positive effect on immobile plant nutrient uptake (Esitken and Turan, 2004; Mansour, 2007); thus increased the growth of plants. These results were in harmony with those obtained by Shehata et al. (2012) and El-Eslamboly \& Abdel-Wahab (2014), they demonstrated that application of magnetic iron increased vegetative growth of cucumber and cantaloupe respectively. 
Regarding the interaction between mineral fertilizer rates and magnetic iron addition, the highest values of all vegetative growth properties resulted from $100 \%$ of mineral fertilizer with adding magnetic iron. Treatment of $75 \%$ mineral fertilizer with adding magnetic iron came in second order without significant differences with $100 \%$ of mineral fertilizer only in some growth properties. The lowest values of all vegetative growth properties resulted from $50 \%$ of mineral fertilizer without magnetic iron.

Table 3: Effect mineral fertilizer rates and magnetic iron on vegetative growth properties of cucumber plants in both seasons

\begin{tabular}{|c|c|c|c|c|c|c|c|c|c|c|c|c|c|c|c|c|}
\hline \multirow{4}{*}{$\begin{array}{l}\text { Magnetic } \\
\text { iron }\end{array}$} & \multicolumn{8}{|c|}{ 2018/2019 season } & \multicolumn{8}{|c|}{$2019 / 2020$ season } \\
\hline & \multicolumn{16}{|c|}{ Fertilizer rate } \\
\hline & \multicolumn{4}{|c|}{$100 \%$} & \multicolumn{2}{|c|}{$50 \%$} & \multicolumn{2}{|c|}{ Mean } & \multicolumn{2}{|c|}{$100 \%$} & \multicolumn{2}{|c|}{$75 \%$} & \multicolumn{2}{|c|}{$50 \%$} & \multicolumn{2}{|c|}{ Mean } \\
\hline & \multicolumn{16}{|c|}{ Plant height (cm) } \\
\hline Without & 243.6 & $\mathrm{c}$ & 228.3 & d & 192.7 & ef & 221.6 & B & 243.3 & $\mathrm{c}$ & 223.7 & d & 198.0 & $\mathrm{e}$ & 221.7 & B \\
\hline With & 265.0 & $\mathrm{a}$ & 253.3 & $\mathrm{~b}$ & 230.3 & $\mathrm{c}$ & 249.6 & A & 267.0 & $\mathrm{a}$ & 253.7 & $\mathrm{~b}$ & 222.7 & $\mathrm{e}$ & 247.8 & A \\
\hline \multirow[t]{2}{*}{ Mean } & 254.3 & A & 240.8 & B & 211.5 & $\mathrm{C}$ & & & 255.2 & A & 238.7 & B & 210.3 & $\mathrm{C}$ & & \\
\hline & \multicolumn{16}{|c|}{ Leaf number/plant } \\
\hline Without & 30.33 & $\mathrm{bc}$ & 25.00 & d & 21.00 & $\mathrm{e}$ & 25.44 & $\mathrm{~B}$ & 32.00 & $\mathrm{~b}$ & 27.00 & bc & 23.00 & $\mathrm{c}$ & 27.33 & B \\
\hline With & 35.66 & $\mathrm{a}$ & 33.00 & $a b$ & 28.00 & $\mathrm{c}$ & 32.22 & A & 37.66 & a & 31.00 & $\mathrm{~b}$ & 30.00 & $\mathrm{~b}$ & 32.88 & A \\
\hline \multirow[t]{2}{*}{ Mean } & 33.00 & A & 29.00 & $\mathrm{~B}$ & 24.50 & $\mathrm{C}$ & & & 24.83 & A & 29.00 & B & 26.50 & $\mathrm{~B}$ & & \\
\hline & \multicolumn{16}{|c|}{ Stem diameter $(\mathrm{cm})$} \\
\hline Without & 1.33 & $\mathrm{c}$ & 1.18 & $\mathrm{e}$ & 0.96 & $\mathrm{f}$ & 1.15 & $\mathrm{~B}$ & 1.43 & $\mathrm{~b}$ & 1.19 & d & 1.04 & $\mathrm{e}$ & 1.22 & B \\
\hline With & 1.45 & $\mathrm{a}$ & 1.37 & $\mathrm{~b}$ & 1.29 & d & 1.38 & $\mathrm{~A}$ & 1.60 & $\mathrm{a}$ & 1.48 & $\mathrm{~b}$ & 1.32 & $\mathrm{c}$ & 1.47 & A \\
\hline \multirow[t]{2}{*}{ Mean } & 1.39 & A & 1.27 & B & 1.31 & $\mathrm{C}$ & & & 1.52 & A & 1.33 & B & 1.18 & $\mathrm{C}$ & & \\
\hline & \multicolumn{16}{|c|}{ Chlorophyll (SPAD) } \\
\hline Without & 35.49 & $a b$ & 30.87 & $\mathrm{c}$ & 28.53 & $\mathrm{e}$ & 31.63 & $\mathrm{~B}$ & 34.43 & $\mathrm{c}$ & 31.79 & $\mathrm{e}$ & 29.05 & $\mathrm{f}$ & 31.76 & B \\
\hline With & 37.02 & $\mathrm{a}$ & 36.44 & $\mathrm{ab}$ & 34.93 & $\mathrm{~b}$ & 36.13 & A & 36.90 & $\mathrm{a}$ & 35.76 & $\mathrm{~b}$ & 33.30 & d & 35.32 & A \\
\hline \multirow[t]{2}{*}{ Mean } & 36.25 & A & 33.66 & B & 31.73 & $\mathrm{C}$ & & & 35.66 & A & 33.77 & B & 31.17 & $\mathrm{C}$ & & \\
\hline & \multicolumn{16}{|c|}{ Shoot fresh weight (kg) } \\
\hline Without & 1.23 & $\mathrm{~b}$ & 0.86 & d & 0.64 & $\mathrm{e}$ & 0.91 & $\mathrm{~B}$ & 1.26 & $\mathrm{c}$ & 0.96 & e & 0.66 & $\mathrm{f}$ & 0.96 & B \\
\hline With & 1.39 & $\mathrm{a}$ & 1.26 & $\mathrm{~b}$ & 0.96 & $\mathrm{c}$ & 1.20 & A & 1.46 & $\mathrm{a}$ & 1.37 & $\mathrm{~b}$ & 0.98 & d & 1.27 & A \\
\hline Mean & 1.31 & A & 1.06 & $\mathrm{~B}$ & 0.80 & $\mathrm{C}$ & & & 1.36 & A & 1.16 & $\mathrm{~B}$ & 0.82 & $\mathrm{C}$ & & \\
\hline
\end{tabular}

Means followed in same column by similar letters are not statistically different at 0.05 level according to Tukey test.

\subsection{The nutritional content of plants}

The nutritional content (NPK) of cucumber plants that are shown in Table 4, explained the effect of the different mineral fertilizer rates and magnetic iron addition on $\mathrm{N}, \mathrm{P}$ and $\mathrm{K}$ content of cucumber plants in the studied seasons. The mineral fertilizer rate of $100 \%$ gave the highest values of $\mathrm{N}, \mathrm{P}$ and $\mathrm{K}$ content of plants followed by $75 \%$ mineral fertilizer, while the lowest $\mathrm{N}, \mathrm{P}$ and $\mathrm{K}$ content obtained by $50 \%$ mineral fertilizer. The increasing N, P and K content in cucumber leaves by $100 \%$ mineral fertilizer might be due to this treatment provided adequate nutritional requirements for plants, consequently the nutrient content of plants has increased (Jilani et al., 2009; Eifediyi and Remison, 2010; Feleafel et al., 2014).

The magnetic iron treatment led to the occurrence of a significant increment in N, P and K content of cucumber plants compared to non-magnetic iron. The good effect of magnetic iron addition on the nutritional status of plants might be due to magnetic iron could enhances soil physical and chemical properties, as well as nutrient uptake by plants (Ismail et al., 2010 and Shahin et al., 2016).

The interaction between mineral fertilizer rates and magnetic iron addition showed significant effect on the nutritional status of cucumber plants. The highest $\mathrm{N}, \mathrm{P}$ and $\mathrm{K}$ content of plants resulted from $100 \%$ mineral fertilizer with adding magnetic iron. Treatment of $75 \%$ mineral fertilizer with adding magnetic iron came in second order, followed by $100 \%$ of mineral fertilizer without magnetic 
iron. The lowest values of $\mathrm{N}, \mathrm{P}$ and $\mathrm{K}$ content in plants resulted from using mineral fertilizer without magnetic iron.

\subsection{Yield of cucumber fruits}

Data illustrated in Table 5 indicate that the yield of cucumber (yield/plot and $\mathrm{m}^{2}$; fruit number/plant), significantly affected by the treatments of mineral fertilizer rates and magnetic iron addition in both seasons. The highest yield and fruit number of cucumber were produced with treatment of $100 \%$ mineral fertilizer. Treatment of $75 \%$ mineral fertilizer came in the second order. Finally, $50 \%$ mineral fertilizer produced the lowest yield and fruit number. The positive effect of $100 \%$ mineral fertilizer on yield of cucumber could be explain by providing adequate nutritional requirements for plants, consequently the nutrient content of plants has increased as shown in Table 4, which improved of vegetative growth parameters. This stimulated photosynthesis in plants, which reflected on increment of yield. Jilani et al. (2009), Eifediyi \& Remison (2010), Feleafel et al. (2014) and Naik et al. (2019) reported similar results.

Table 4: Effect mineral fertilizer rates and magnetic iron on nutrient content of cucumber plants in both seasons

\begin{tabular}{|c|c|c|c|c|c|c|c|c|c|c|c|c|c|c|c|c|}
\hline \multirow{4}{*}{$\begin{array}{l}\text { Magnetic } \\
\text { iron }\end{array}$} & \multicolumn{8}{|c|}{ 2018/2019 season } & \multicolumn{8}{|c|}{$2019 / 2020$ season } \\
\hline & \multicolumn{16}{|c|}{ Fertilizer rate } \\
\hline & \multicolumn{2}{|c|}{$100 \%$} & \multicolumn{2}{|c|}{$75 \%$} & \multicolumn{2}{|c|}{$50 \%$} & \multicolumn{2}{|c|}{ Mean } & \multicolumn{2}{|c|}{$100 \%$} & \multicolumn{2}{|c|}{$75 \%$} & \multicolumn{2}{|c|}{$50 \%$} & \multicolumn{2}{|c|}{ Mean } \\
\hline & \multicolumn{16}{|c|}{ N (\%) } \\
\hline Without & 3.474 & $\mathrm{c}$ & 2.315 & $\mathrm{e}$ & 2.059 & $\mathrm{f}$ & 2.616 & B & 3.529 & $\mathrm{bc}$ & 3.012 & $\mathrm{~d}$ & 2.411 & $\mathrm{e}$ & 2.984 & $\mathrm{C}$ \\
\hline With & 4.071 & $\mathrm{a}$ & 3.717 & $\mathrm{~b}$ & 3.187 & $\mathrm{~d}$ & 3.658 & A & 4.193 & $\mathrm{a}$ & 3.828 & $a b$ & 3.201 & $\mathrm{~cd}$ & 2.741 & B \\
\hline \multirow[t]{2}{*}{ Mean } & 3.772 & A & 3.016 & $\mathrm{~B}$ & 2.623 & $\mathrm{C}$ & & & 3.861 & A & 3.420 & $\mathrm{~B}$ & 2.806 & $\mathrm{C}$ & & \\
\hline & \multicolumn{16}{|c|}{$P(\%)$} \\
\hline Without & 0.446 & $\mathrm{c}$ & 0.278 & $\mathrm{e}$ & 0.239 & $\mathrm{f}$ & 0.321 & $\mathrm{~B}$ & 0.478 & $\mathrm{c}$ & 0.291 & $\mathrm{e}$ & 0.237 & $\mathrm{f}$ & 0.335 & B \\
\hline With & 0.500 & $\mathrm{a}$ & 0.476 & $\mathrm{~b}$ & 0.403 & $\mathrm{~d}$ & 0.459 & A & 0.525 & $\mathrm{a}$ & 0.498 & $\mathrm{~b}$ & 0.445 & $\mathrm{~d}$ & 0.486 & A \\
\hline \multirow[t]{2}{*}{ Mean } & 0.473 & A & 0.377 & B & 0.321 & $\mathrm{C}$ & & & 0.502 & A & 0.390 & B & 0.341 & $\mathrm{C}$ & & \\
\hline & \multicolumn{16}{|c|}{ K (\%) } \\
\hline Without & 3.956 & $\mathrm{c}$ & 2.778 & $\mathrm{e}$ & 2.401 & $\mathrm{f}$ & 3.046 & B & 3.994 & $\mathrm{c}$ & 3.734 & d & 2.357 & $\mathrm{f}$ & 3.362 & B \\
\hline With & 4.336 & $\mathrm{a}$ & 3.981 & $\mathrm{~b}$ & 3.684 & $\mathrm{~d}$ & 4.000 & A & 4.381 & $\mathrm{a}$ & 4.084 & $\mathrm{~b}$ & 2.878 & e & 3.781 & A \\
\hline Mean & 4.146 & A & 3.379 & $\mathrm{~B}$ & 3.043 & $\mathrm{C}$ & & & 4.188 & A & 3.909 & B & 2.617 & $\mathrm{C}$ & & \\
\hline
\end{tabular}

Means followed in same column by similar letters are not statistically different at 0.05 level according to Tukey test.

Magnetic iron addition treatment increased the yield and fruit number of cucumber compared to non-magnetic iron treatment. The superiority of yield with adding magnetic iron might be attribute the positive effect of magnetic iron on immobile plant nutrient uptake (Esitken and Turan, 2004; Mansour, 2007). Hence, providing nutrients in available for absorption and good plant growth, which reflected on increment of yield. These results were in line with those obtained by El-Hifny et al. (2008) on cauliflower, Ali et al. (2011) and Taha et al. (2011) on pepper; Shehata et al. (2012) on cucumber, ElEslamboly \& Abdel-Wahab (2014) on cantaloupe and El-Gizawy et al. (2016) on potato.

Regarding the interaction between mineral fertilizer rates and magnetic iron addition, significant effected on yield and fruit number of cucumber. The highest yield and fruit number were produced using $100 \%$ mineral fertilizer with adding magnetic iron. Treatment of $75 \%$ mineral fertilizer with adding magnetic iron came in second order, followed by $100 \%$ of mineral fertilizer without magnetic iron. Applying 50\% of mineral fertilizer without magnetic iron gave the lowest yield and fruit number. This negative effect can be ascribe to that mineral fertilizer at $50 \%$ was not sufficient for nutritional requirements of plants, led to low growth of plants, which reflected on the low yield. These results are supported by the studies of Feleafel et al. (2014) and Naik et al. (2019). 
Table 5: Effect mineral fertilizer rates and magnetic iron on yield and fruit number of cucumber in both seasons

\begin{tabular}{|c|c|c|c|c|c|c|c|c|c|c|c|c|c|c|c|c|}
\hline \multirow{4}{*}{$\begin{array}{l}\text { Magnetic } \\
\text { iron }\end{array}$} & \multicolumn{8}{|c|}{ 2018/2019 season } & \multicolumn{8}{|c|}{$2019 / 2020$ season } \\
\hline & \multicolumn{16}{|c|}{ Fertilizer rate } \\
\hline & \multicolumn{2}{|c|}{$100 \%$} & \multicolumn{2}{|c|}{$75 \%$} & \multicolumn{2}{|l|}{$50 \%$} & \multicolumn{2}{|c|}{ Mean } & \multicolumn{2}{|c|}{$100 \%$} & \multicolumn{2}{|c|}{$75 \%$} & \multicolumn{2}{|c|}{$50 \%$} & \multicolumn{2}{|l|}{ Mean } \\
\hline & \multicolumn{16}{|c|}{ Yield/plot $\left(\mathrm{kg} / 4.5 \mathrm{~m}^{2}\right)$} \\
\hline Without & 32.36 & $\mathrm{c}$ & 24.57 & $\mathrm{e}$ & 14.18 & $\mathrm{f}$ & 23.70 & B & 32.58 & $\mathrm{c}$ & 24.93 & $\mathrm{e}$ & 14.49 & $\mathrm{f}$ & 24.00 & B \\
\hline With & 33.93 & $\mathrm{a}$ & 32.85 & $\mathrm{~b}$ & 27.54 & $\mathrm{~d}$ & 31.44 & A & 35.15 & $\mathrm{a}$ & 32.99 & $\mathrm{~b}$ & 27.86 & $\mathrm{~d}$ & 32.00 & A \\
\hline \multirow[t]{2}{*}{ Mean } & 33.14 & A & 28.71 & $\mathrm{~B}$ & 20.86 & $\mathrm{C}$ & & & 33.86 & A & 28.96 & $\mathrm{~B}$ & 21.17 & $\mathrm{C}$ & & \\
\hline & \multicolumn{16}{|c|}{ Yield $\left(\mathrm{kg} / \mathrm{m}^{2}\right)$} \\
\hline Without & 7.19 & $\mathrm{c}$ & 5.46 & $\mathrm{e}$ & 3.15 & $\mathrm{f}$ & 5.27 & $\mathrm{~B}$ & 7.24 & $\mathrm{c}$ & 5.54 & $\mathrm{e}$ & 3.22 & $\mathrm{f}$ & 5.33 & B \\
\hline With & 7.54 & $\mathrm{a}$ & 7.30 & $\mathrm{~b}$ & 6.12 & $\mathrm{~d}$ & 6.99 & A & 7.81 & $\mathrm{a}$ & 7.33 & $\mathrm{~b}$ & 6.19 & $\mathrm{~d}$ & 7.11 & A \\
\hline \multirow[t]{2}{*}{ Mean } & 7.50 & A & 6.40 & B & 4.64 & $\mathrm{C}$ & & & 7.53 & A & 6.44 & $\mathrm{~B}$ & 4.71 & $\mathrm{C}$ & & \\
\hline & \multicolumn{16}{|c|}{ Fruit number /plant } \\
\hline Without & 31.89 & $\mathrm{bc}$ & 25.52 & $\mathrm{e}$ & 17.53 & $\mathrm{f}$ & 24.98 & B & 32.08 & $\mathrm{bc}$ & 26.26 & e & 17.66 & $\mathrm{f}$ & 25.33 & B \\
\hline With & 32.61 & $\mathrm{a}$ & 31.96 & $\mathrm{~b}$ & 29.13 & $\mathrm{~d}$ & 31.23 & A & 33.25 & $\mathrm{a}$ & 32.16 & $\mathrm{~b}$ & 29.36 & $\mathrm{~d}$ & 31.59 & A \\
\hline Mean & 32.25 & A & 28.74 & B & 22.33 & $\mathrm{C}$ & & & 32.67 & A & 29.21 & $\mathrm{~B}$ & 22.51 & $\mathrm{C}$ & & \\
\hline
\end{tabular}

Means followed in same column by similar letters are not statistically different at 0.05 level according to Tukey test.

\subsection{Fruit quality}

Data in Table 6 show that cucumber plants were treated with magnetic iron significantly increased their fruit quality expressed as physical properties (fruit weight, fruit length, fruit diameter and fruit firmness) and chemical properties (TSS\% and ascorbic acid content) compared with nonmagnetic iron treatment. In this respect, treatment of $100 \%$ of mineral fertilizer with adding magnetic iron was the most effective treatment for improving fruit quality, followed by $75 \%$ of mineral fertilizer with adding magnetic iron with no significant differences between them of these characters except $\mathrm{TSS} \%$ and ascorbic acid content in the second season. On the other hand, the lowest values of these characters resulted by $50 \%$ of mineral fertilizer without magnetic iron. Magnetic iron treatments might help in improving fruit quality due to the improvement of vegetative growth parameters of cucumber plants in response to application of magnetic iron which may result in improving quality of cucumber fruit such as fruit length, diameter, total soluble solids content and firmness compared to non-treated plants which had the lowest values (El-Zawily et al., 2018). In this concern, Rezaiiasl et al. (2012) and Shahin et al. (2016) stated that cucumber plants either treated with magnetite or magnetized water increased fruit quality of cucumber fruits may be due to their beneficial effects on vegetative growth characters. Taha et al. (2011) revealed that treated pepper plants with magnetite at (4g/pot) progressive increases in V.C and capsaicin contents. In addition, Mohamed et al. (2013) found that magnetite treatments improved orange fruit peel quality, where the peel thickness and firmness has increased; fruit peel was more lightness and had high good color quality, so it seems more attractive. Also, concluded that magnetite for giving the high fruit peel quality which very important characteristics especially when fruits tended to be exported.

\subsection{Evaluation of nutrient use efficiency}

Data in Table 7 clear that using 50\% mineral fertilizer achieved the highest nutrient use efficiency. Treatment of $75 \%$ mineral fertilizer came in the second order. Whereas, the lowest nutrient use efficiency was resulted from applying $100 \%$ mineral fertilizer. These results are supported by the studies of Qu et al. (2019) and Singh et al. (2019), they stated that the highest NUE was observed at the lowest level of fertilization.

Addition of magnetic iron with different mineral fertilizer rates achieved superiority in nutrient use efficiency compared to non-adding magnetic iron. This might be due to the role of magnetic iron, which helps to moderate the soil temperature, improve water hold capacity and crop nutrition (Ismail et al., 2010). 
The highest nutrient use efficiency was true using 50\% mineral fertilizer with adding magnetic iron, followed by $75 \%$ mineral fertilizer with adding magnetic iron, then $100 \%$ mineral fertilizer with adding magnetic iron, while the lowest nutrient use efficiency was obtained by $50 \%$ mineral fertilizer without magnetic iron.

Table 6: Effect of mineral fertilizer rates and magnetic iron on physical and chemical properties of cucumber fruits in both seasons

\begin{tabular}{|c|c|c|c|c|c|c|c|c|c|c|c|c|c|c|c|c|}
\hline \multirow{4}{*}{$\begin{array}{l}\text { Magnetic } \\
\text { iron }\end{array}$} & \multicolumn{8}{|c|}{ 2018/2019 season } & \multicolumn{8}{|c|}{$2019 / 2020$ season } \\
\hline & \multicolumn{16}{|c|}{ Fertilizer rate } \\
\hline & \multicolumn{2}{|c|}{$100 \%$} & \multicolumn{2}{|c|}{$75 \%$} & \multicolumn{2}{|c|}{$50 \%$} & \multicolumn{2}{|c|}{ Mean } & \multicolumn{2}{|c|}{$100 \%$} & \multicolumn{2}{|c|}{$75 \%$} & \multicolumn{2}{|c|}{$50 \%$} & \multicolumn{2}{|c|}{ Mean } \\
\hline & \multicolumn{16}{|c|}{ Fruit weight (g) } \\
\hline Without & 79.15 & $\mathrm{~b}$ & 76.38 & $\mathrm{c}$ & 74.54 & $\mathrm{~d}$ & 76.69 & $\mathrm{~B}$ & 76.56 & $\mathrm{~b}$ & 74.45 & $\mathrm{c}$ & 72.06 & $\mathrm{~d}$ & 74.36 & B \\
\hline With & 99.16 & $\mathrm{a}$ & 98.43 & $\mathrm{a}$ & 78.68 & $\mathrm{~b}$ & 92.09 & $\mathrm{~A}$ & 97.12 & $\mathrm{a}$ & 96.29 & $\mathrm{a}$ & 76.09 & $\mathrm{bc}$ & 89.83 & A \\
\hline \multirow[t]{2}{*}{ Mean } & 89.16 & A & 87.43 & $\mathrm{~B}$ & 79.63 & $\mathrm{C}$ & & & 86.86 & A & 85.36 & A & 74.06 & B & & \\
\hline & \multicolumn{16}{|c|}{ Fruit length (cm) } \\
\hline Without & 12.83 & $\mathrm{~b}$ & 12.36 & $\mathrm{~cd}$ & 12.03 & $\mathrm{~d}$ & 12.41 & $\mathrm{~B}$ & 11.70 & $\mathrm{~b}$ & 11.33 & $\mathrm{c}$ & 11.03 & $\mathrm{~d}$ & 11.35 & B \\
\hline With & 14.76 & a & 14.73 & $\mathrm{a}$ & 12.63 & $\mathrm{bc}$ & 14.04 & $\mathrm{~A}$ & 14.20 & $\mathrm{a}$ & 14.13 & $\mathrm{a}$ & 11.53 & $\mathrm{bc}$ & 13.28 & A \\
\hline \multirow[t]{2}{*}{ Mean } & 13.83 & A & 13.56 & $\mathrm{~B}$ & 12.33 & $\mathrm{C}$ & & & 12.96 & A & 12.73 & A & 11.30 & $\mathrm{~B}$ & & \\
\hline & \multicolumn{16}{|c|}{ Fruit diameter $(\mathrm{cm})$} \\
\hline Without & 2.80 & $\mathrm{a}$ & 2.36 & $\mathrm{~b}$ & 2.16 & $\mathrm{~b}$ & 2.44 & $\mathrm{~B}$ & 2.63 & $\mathrm{a}$ & 2.16 & $\mathrm{bc}$ & 1.93 & $\mathrm{c}$ & 2.24 & B \\
\hline With & 2.96 & $\mathrm{a}$ & 2.93 & $\mathrm{a}$ & 2.66 & $\mathrm{a}$ & 2.85 & $\mathrm{~A}$ & 2.80 & $\mathrm{a}$ & 2.73 & $\mathrm{a}$ & 2.43 & $a b$ & 2.65 & A \\
\hline \multirow[t]{2}{*}{ Mean } & 2.88 & $\mathrm{~A}$ & 2.65 & $\mathrm{~B}$ & 2.41 & $\mathrm{C}$ & & & 2.71 & A & 2.45 & $\mathrm{~B}$ & 2.18 & $\mathrm{C}$ & & \\
\hline & \multicolumn{16}{|c|}{ Firmness $\left(\mathrm{kg} / \mathrm{cm}^{2}\right)$} \\
\hline Without & 4.03 & $\mathrm{~b}$ & 3.83 & $\mathrm{~b}$ & 3.73 & $\mathrm{~b}$ & 3.86 & $\mathrm{~B}$ & 3.83 & $\mathrm{~b}$ & 3.70 & $\mathrm{~b}$ & 3.56 & $\mathrm{~b}$ & 3.70 & B \\
\hline With & 5.43 & $\mathrm{a}$ & 5.43 & $\mathrm{a}$ & 3.90 & $\mathrm{~b}$ & 4.98 & $\mathrm{~A}$ & 5.43 & $\mathrm{a}$ & 5.26 & $\mathrm{a}$ & 3.73 & $\mathrm{~b}$ & 4.81 & A \\
\hline \multirow[t]{2}{*}{ Mean } & 4.83 & $\mathrm{~A}$ & 4.63 & A & 3.81 & $\mathrm{~B}$ & & & 4.63 & A & 4.48 & A & 3.65 & $\mathrm{~B}$ & & \\
\hline & \multicolumn{16}{|c|}{ T.S.S (\%) } \\
\hline Without & 3.30 & $\mathrm{bc}$ & 3.10 & $\mathrm{c}$ & 2.96 & $\mathrm{c}$ & 3.13 & $\mathrm{~B}$ & 2.90 & $\mathrm{c}$ & 2.63 & $\mathrm{~cd}$ & 2.50 & $\mathrm{~d}$ & 2.67 & B \\
\hline With & 3.80 & $\mathrm{a}$ & 3.60 & $a b$ & 3.23 & $\mathrm{bc}$ & 3.54 & A & 3.50 & $\mathrm{a}$ & 3.20 & $\mathrm{~b}$ & 2.76 & $\mathrm{~cd}$ & 3.15 & A \\
\hline \multirow[t]{2}{*}{ Mean } & 3.56 & A & 3.35 & $\mathrm{~B}$ & 3.10 & $\mathrm{C}$ & & & 3.20 & A & 2.91 & $\mathrm{~B}$ & 2.63 & $\mathrm{C}$ & & \\
\hline & \multicolumn{16}{|c|}{ Ascorbic acid (mg/100 g FW) } \\
\hline Without & 2.90 & $\mathrm{~b}$ & 2.87 & $\mathrm{c}$ & 2.85 & $\mathrm{~d}$ & 2.88 & $\mathrm{~B}$ & 2.83 & $\mathrm{c}$ & 2.81 & $\mathrm{c}$ & 2.79 & $\mathrm{~d}$ & 2.81 & B \\
\hline With & 2.99 & $\mathrm{a}$ & 2.98 & $\mathrm{a}$ & 2.88 & $\mathrm{bc}$ & 2.95 & A & 2.96 & $\mathrm{a}$ & 2.94 & $\mathrm{~b}$ & 2.83 & $\mathrm{c}$ & 2.91 & A \\
\hline Mean & 2.95 & A & 2.93 & B & 2.86 & $\mathrm{C}$ & & & 2.90 & A & 2.88 & B & 2.81 & $\mathrm{C}$ & & \\
\hline
\end{tabular}

Means followed in same column by similar letters are not statistically different at 0.05 level according to Tukey test.

Table 7: Evaluation of nutrient use efficiency (NUE) of different treatments of cucumber in both seasons (2018/2019 and 2019/2020)

\begin{tabular}{|c|c|c|c|c|c|c|c|}
\hline \multirow{2}{*}{ Treatments } & \multirow{2}{*}{$\begin{array}{c}\text { Fertilizer } \\
\left(\mathbf{k g} / \mathbf{m}^{2}\right)\end{array}$} & \multicolumn{3}{|c|}{ Yield $\left(\mathrm{kg} / \mathrm{m}^{2}\right)$} & \multicolumn{3}{|c|}{$\mathrm{NUE} / \mathrm{m}^{2}$} \\
\hline & & $1^{\text {st }}$ season & $2^{\text {nd }}$ season & Mean & $1^{\text {st }}$ season & $2^{\text {nd }}$ season & Mean \\
\hline $100 \% \mathrm{~F}$ & 0.125 & 7.185 & 7.241 & 7.213 & 57.481 & 57.926 & 57.704 \\
\hline $75 \% \mathrm{~F}$ & 0.094 & 5.463 & 5.537 & 5.500 & 58.272 & 59.062 & 58.667 \\
\hline $50 \%$ F & 0.063 & 3.152 & 3.219 & 3.185 & 50.430 & 51.496 & 50.963 \\
\hline $100 \% F+M$ & 0.125 & 7.537 & 7.815 & 7.676 & 60.296 & 62.519 & 61.407 \\
\hline $75 \% F+M$ & 0.094 & 7.296 & 7.333 & 7.315 & 77.827 & 78.222 & 78.025 \\
\hline $50 \% \mathbf{F}+\mathbf{M}$ & 0.063 & 6.115 & 6.185 & 6.150 & 97.843 & 98.963 & 98.403 \\
\hline
\end{tabular}

$\mathrm{F}=$ mineral fertilizer of $\mathrm{NPK}, \mathrm{M}=$ without magnetic iron 


\subsection{Storage experiment}

\subsubsection{Weight loss percentage}

Data in Table 8 show that weight loss percentage of cucumber fruits was increased considerably and consistently with the prolongation of storage period plus shelf life in the two seasons. Similar results were reported by Shehata et al. (2018) and Saad (2019) on cucumber. The weight loss is a natural consequence of the catabolism of horticultural products. The loss in weight may be attributes to respiration and other senescence related metabolic processes during storage (Wills et al., 1998).

In general, the interaction between pre-harvest treatments and storage periods plus shelf life was significant in both seasons. Cucumber fruits obtained from plants treated with $100 \%$ or $75 \%$ of mineral fertilizers with adding magnetic iron reduced weight $10 \mathrm{ss} \%$ of fruits during all storage period with significant differences between them, followed by $100 \%$ of mineral fertilizers without magnetic iron. On the other hand, the highest values of weight loss percentages are recorded from applying the treatment of $50 \%$ of mineral fertilizers without magnetic iron treatment. These results were achieved in the two seasons. Such results may be due to the beneficial effect of magnetic iron (Shahin et al., 2016) on vegetative growth characters and chemical composition of cucumber fruits, which in turn maintained the metabolic homeostasis after harvest and reduce dehydration of fruits.

Table 8: Effect of mineral fertilizer rates and magnetic iron on weight loss $\%$ of cucumber fruits during cold storage $\left(10^{\circ} \mathrm{C}\right)$ plus shelf life $\left(15^{\circ} \mathrm{C}\right)$ in both seasons

\begin{tabular}{|c|c|c|c|c|c|c|c|c|c|c|c|c|c|c|}
\hline \multirow{4}{*}{$\begin{array}{l}\text { Treatments } \\
100 \% \mathrm{~F}\end{array}$} & \multicolumn{14}{|c|}{ Storage period (days) } \\
\hline & \multicolumn{14}{|c|}{ 2018/2019 season } \\
\hline & \multicolumn{2}{|l|}{ 0 } & \multicolumn{2}{|c|}{$0+2$} & \multicolumn{2}{|c|}{$4+2$} & \multicolumn{2}{|c|}{$8+2$} & \multicolumn{2}{|c|}{$12+2$} & \multicolumn{2}{|c|}{$16+2$} & \multicolumn{2}{|c|}{ Mean } \\
\hline & 0.00 & $\mathrm{r}$ & 0.30 & $\mathrm{pq}$ & 0.93 & $\mathrm{kj}$ & 1.74 & $\mathrm{~h}$ & 2.38 & $\mathrm{f}$ & 3.17 & $d$ & 1.42 & $\mathrm{D}$ \\
\hline $75 \% \mathrm{~F}$ & 0.00 & $\mathrm{r}$ & 0.36 & op & 1.11 & $\mathrm{j}$ & 2.17 & $\mathrm{~g}$ & 2.85 & $\mathrm{e}$ & 3.78 & $\mathrm{~b}$ & 1.71 & B \\
\hline $50 \% \mathrm{~F}$ & 0.00 & $\mathrm{r}$ & 0.44 & no & 1.33 & $\mathrm{i}$ & 2.37 & $f$ & 3.12 & d & 4.19 & $\mathrm{a}$ & 1.91 & A \\
\hline $100 \% F+M$ & 0.00 & $\mathrm{r}$ & 0.16 & $\mathrm{qr}$ & 0.52 & $\mathrm{mn}$ & 0.61 & $\operatorname{lm}$ & 1.05 & $\mathrm{kj}$ & 1.40 & $\mathrm{i}$ & 0.62 & $\mathrm{~F}$ \\
\hline $75 \% \mathrm{~F}+\mathrm{M}$ & 0.00 & $\mathrm{r}$ & 0.18 & $\mathrm{qr}$ & 0.65 & 1 & 0.88 & $\mathrm{k}$ & 1.42 & $\mathrm{i}$ & 1.90 & $\mathrm{~h}$ & 0.84 & $\mathrm{E}$ \\
\hline $50 \% \mathrm{~F}+\mathrm{M}$ & 0.00 & $\mathrm{r}$ & 0.33 & $\mathrm{pq}$ & 1.08 & $\mathrm{j}$ & 1.93 & $\mathrm{~h}$ & 2.65 & $\mathrm{e}$ & 3.56 & $\mathrm{c}$ & 1.59 & $\mathrm{C}$ \\
\hline \multirow[t]{2}{*}{ Mean } & 0.00 & $\mathrm{~F}$ & 0.29 & $\mathrm{E}$ & 0.94 & $\mathrm{D}$ & 1.62 & $\mathrm{C}$ & 2.24 & B & 3.00 & A & & \\
\hline & \multicolumn{14}{|c|}{$2019 / 2020$ season } \\
\hline $100 \%$ F & 0.00 & $\mathrm{r}$ & 0.34 & $\mathrm{pq}$ & 0.98 & $\mathrm{kj}$ & 1.81 & $\mathrm{~h}$ & 2.44 & $f$ & 3.25 & d & 1.47 & $\mathrm{D}$ \\
\hline $75 \% \mathrm{~F}$ & 0.00 & $\mathrm{r}$ & 0.41 & op & 1.15 & $\mathrm{j}$ & 2.23 & g & 2.93 & $\mathrm{e}$ & 3.85 & $\mathrm{~b}$ & 1.76 & B \\
\hline $50 \% \mathrm{~F}$ & 0.00 & $\mathrm{r}$ & 0.48 & no & 1.37 & $\mathrm{i}$ & 2.41 & $\mathrm{f}$ & 3.18 & d & 4.27 & $\mathrm{a}$ & 1.95 & A \\
\hline $100 \% F+M$ & 0.00 & $\mathrm{r}$ & 0.20 & $\mathrm{qr}$ & 0.55 & $\mathrm{mn}$ & 0.68 & $\operatorname{lm}$ & 1.10 & $\mathrm{kj}$ & 1.46 & $\mathrm{i}$ & 0.67 & $\mathrm{~F}$ \\
\hline $75 \% \mathrm{~F}+\mathrm{M}$ & 0.00 & $\mathrm{r}$ & 0.23 & $\mathrm{qr}$ & 0.69 & 1 & 0.93 & $\mathrm{k}$ & 1.45 & $\mathrm{i}$ & 1.97 & $\mathrm{~h}$ & 0.88 & E \\
\hline $50 \% \mathbf{F}+\mathbf{M}$ & 0.00 & $\mathrm{r}$ & 0.37 & $\mathrm{pq}$ & 1.09 & $\mathrm{j}$ & 2.00 & $\mathrm{~h}$ & 2.72 & $\mathrm{e}$ & 3.66 & $\mathrm{c}$ & 1.64 & $\mathrm{C}$ \\
\hline Mean & 0.00 & $\mathrm{~F}$ & 0.34 & $\mathrm{E}$ & 0.97 & $\mathrm{D}$ & 1.68 & $\mathrm{C}$ & 2.30 & B & 3.07 & A & & \\
\hline
\end{tabular}

Means followed in same column by similar letters are not statistically different at 0.05 level according to Tukey test. $\mathrm{F}=$ mineral fertilizer of NPK, $\mathrm{M}=$ magnetic iron

\subsubsection{General appearance}

Data in Table 9 indicated that general appearance of cucumber fruits decreased significantly with the prolongation of storage period plus shelf life. Similar results were reported by Shehata et al. (2018) and Saad (2019) on cucumber. The decrease of general appearance of cucumber fruits during storage might be due to shriveling, pitting, color change of fruits and decay (Shehata et al., 2009 and Rageh and Abou-Elwafa, 2017).

Concerning the effect of pre-harvest treatments, general appearance of cucumber fruits obtained from plants treated with $100 \%$ or $75 \%$ of mineral fertilizer with adding magnetite were the most effective treatments for maintaining general appearance compared with the other treatments. However, cucumber fruits obtained from plants treated with $100 \%$ or $75 \%$ of mineral fertilizer with adding magnetic iron treatments had the best general appearance with significant differences between them. In other words, these treatments gave the highest score of appearance; while fruits obtained from $75 \%$ or 
$50 \%$ of mineral fertilizer without magnetic iron treatments obtained the lowest values in this concern with no significant differences between them. These results were true in the two seasons. Such results may be due to the useful role of iron in reducing weight loss percentage and maintaining green color during storage (Atrees and Mohamed, 2014).

In general, the interaction between pre-harvest treatments and storage periods plus shelf life was significant in the two seasons. Results indicated that cucumber fruits obtained from plants treated with $100 \%$ of mineral fertilizer with adding magnetite did not exhibit any changes in their appearance till 12 days at $10^{\circ} \mathrm{C}+2$ days at $15{ }^{\circ} \mathrm{C}$ as a shelf life and showed good appearance up to 16 days at $10^{\circ} \mathrm{C}$ + the shelf life. On the other hand, fruits obtained from $100 \%, 75 \%$ and $50 \%$ of mineral fertilizer without magnetic iron treatments and $50 \%$ of mineral fertilizer with adding magnetite had the unsalable appearance at the end of storage period plus shelf life, indicating the absence of freshness and hardly acceptable or unacceptable appearance for marketing.

Table 9: Effect of mineral fertilizer rates and magnetite on general appearance score of cucumber fruits during cold storage $\left(10^{\circ} \mathrm{C}\right)$ plus shelf life $\left(15^{\circ} \mathrm{C}\right)$ in both seasons

\begin{tabular}{|c|c|c|c|c|c|c|c|c|c|c|c|c|c|c|}
\hline \multirow{4}{*}{$\begin{array}{l}\text { Treatments } \\
100 \% \mathrm{~F}\end{array}$} & \multicolumn{14}{|c|}{ Storage period (days) } \\
\hline & \multicolumn{14}{|c|}{ 2018/2019 season } \\
\hline & \multicolumn{2}{|l|}{$\mathbf{0}$} & \multicolumn{2}{|c|}{$0+2$} & \multicolumn{2}{|c|}{$4+2$} & \multicolumn{2}{|c|}{$8+2$} & \multicolumn{2}{|c|}{$12+2$} & \multicolumn{2}{|c|}{$16+2$} & \multicolumn{2}{|c|}{ Mean } \\
\hline & 9.00 & $\mathrm{a}$ & 9.00 & a & 7.67 & $\mathrm{bc}$ & 5.67 & d & 2.33 & hi & 1.67 & $\mathrm{ij}$ & 5.89 & $\mathrm{C}$ \\
\hline $75 \% \mathrm{~F}$ & 9.00 & $\mathrm{a}$ & 9.00 & $\mathrm{a}$ & 6.33 & $\mathrm{bc}$ & 4.33 & de & 1.67 & $\mathrm{ij}$ & 1.00 & $\mathrm{j}$ & 5.22 & $\mathrm{DE}$ \\
\hline $50 \% \mathrm{~F}$ & 9.00 & $\mathrm{a}$ & 9.00 & $\mathrm{a}$ & 5.67 & d & 3.67 & g & 1.00 & $\mathrm{j}$ & 1.00 & $\mathrm{j}$ & 4.89 & $\mathrm{E}$ \\
\hline $100 \% F+M$ & 9.00 & $\mathrm{a}$ & 9.00 & $\mathrm{a}$ & 9.00 & $\mathrm{a}$ & 9.00 & $\mathrm{ab}$ & 8.33 & $a b$ & 7.00 & $a b$ & 8.56 & A \\
\hline $75 \% \mathrm{~F}+\mathrm{M}$ & 9.00 & a & 9.00 & a & 8.33 & $\mathrm{a}$ & 7.00 & $\mathrm{ab}$ & 5.00 & de & 3.00 & gh & 6.89 & B \\
\hline $50 \%$ F + M & 9.00 & $\mathrm{a}$ & 9.00 & $\mathrm{a}$ & 7.00 & $\mathrm{~cd}$ & 5.00 & ef & 2.33 & hi & 1.67 & $\mathrm{ij}$ & 5.67 & $\mathrm{CD}$ \\
\hline \multirow[t]{2}{*}{ Mean } & 9.00 & A & 9.00 & A & 7.33 & B & 5.78 & $\mathrm{C}$ & 3.44 & $\mathrm{D}$ & 2.56 & $\mathrm{E}$ & & \\
\hline & \multicolumn{14}{|c|}{$2019 / 2020$ season } \\
\hline $100 \%$ F & 9.00 & $\mathrm{a}$ & 9.00 & $\mathrm{a}$ & 7.00 & $\mathrm{bc}$ & 5.00 & $\mathrm{e}$ & 1.67 & $\mathrm{ij}$ & 1.00 & $\mathrm{j}$ & 5.44 & $\mathrm{C}$ \\
\hline $75 \% \mathrm{~F}$ & 9.00 & $\mathrm{a}$ & 9.00 & $\mathrm{a}$ & 5.67 & de & 3.67 & gh & 1.00 & $\mathrm{j}$ & 1.00 & $\mathrm{j}$ & 4.89 & $\mathrm{CD}$ \\
\hline $50 \%$ F & 9.00 & $\mathrm{a}$ & 9.00 & $\mathrm{a}$ & 5.00 & ef & 3.00 & hi & 1.00 & $\mathrm{j}$ & 1.00 & $\mathrm{j}$ & 4.67 & $\mathrm{D}$ \\
\hline $100 \% \mathrm{~F}+\mathrm{M}$ & 9.00 & $\mathrm{a}$ & 9.00 & $\mathrm{a}$ & 9.00 & $\mathrm{a}$ & 9.00 & $\mathrm{a}$ & 8.33 & $a b$ & 7.00 & $\mathrm{bc}$ & 8.56 & A \\
\hline $75 \% F+M$ & 9.00 & $\mathrm{a}$ & 9.00 & $\mathrm{a}$ & 7.67 & $a b$ & 7.00 & $\mathrm{bc}$ & 4.33 & $\mathrm{fg}$ & 3.00 & hi & 6.67 & B \\
\hline $50 \% \mathbf{F}+\mathbf{M}$ & 9.00 & $\mathrm{a}$ & 9.00 & $\mathrm{a}$ & 6.33 & $\mathrm{~cd}$ & 4.33 & ef & 1.67 & hi & 1.00 & $\mathrm{j}$ & 5.22 & $\mathrm{CD}$ \\
\hline Mean & 9.00 & A & 9.00 & A & 6.78 & B & 5.33 & $\mathrm{C}$ & 3.00 & $\mathrm{D}$ & 2.33 & $\mathrm{E}$ & & \\
\hline
\end{tabular}

Means followed in same column by similar letters are not statistically different at 0.05 level according to Tukey test. $\mathrm{F}=$ mineral fertilizer of NPK, $\mathrm{M}=$ magnetic iron

\subsubsection{Color ( $L$ value)}

The L color of cucumber fruits is one of the most important quality factors of fresh cucumber for consumer preference. Data in Table 10 show that there was a significant decrease in L value with increasing storage period plus shelf life for all pre-harvest treatments, showing darker fruits. These results were true in the two seasons and in agreement with those of Rageh and Abou El-wafa (2017) and Saad (2019).

Concerning the effect of pre-harvest treatments, cucumber fruits obtained from plants treated with $100 \%$ or $75 \%$ of mineral fertilizer with adding magnetic iron had significantly higher L values indicating lighter fruits with significant differences between them during cold storage plus shelf life in the two seasons, while those obtained from $50 \%$ of mineral fertilizer without magnetite had darker color (low L value). Fruits obtained from $100 \%$ of mineral fertilizer without magnetic iron or $50 \%$ of mineral fertilizer with adding magnetic iron were less effective in this concern. These results were true in the two seasons. Such results may be due to the beneficial effect of magnetic iron treatments which improved orange fruit peel quality, fruit peel was more lightness and had high good color quality, so it seems more attractive (Mohamed et al., 2013). 
Table 10: Effect of mineral fertilizer rates and magnetic iron on L. color of cucumber fruits during cold storage $\left(10^{\circ} \mathrm{C}\right)$ plus shelf life $\left(15^{\circ} \mathrm{C}\right)$ in both seasons

\begin{tabular}{|c|c|c|c|c|c|c|c|c|c|c|c|c|c|c|}
\hline \multirow{4}{*}{$\begin{array}{l}\text { Treatments } \\
100 \% \mathrm{~F}\end{array}$} & \multicolumn{14}{|c|}{ Storage period (days) } \\
\hline & \multicolumn{14}{|c|}{ 2018/2019 season } \\
\hline & \multicolumn{2}{|l|}{$\mathbf{0}$} & \multicolumn{2}{|c|}{$\mathbf{0}+\mathbf{2}$} & \multicolumn{2}{|c|}{$4+2$} & \multicolumn{2}{|c|}{$8+2$} & \multicolumn{2}{|c|}{$12+2$} & \multicolumn{2}{|c|}{$16+2$} & \multicolumn{2}{|c|}{ Mean } \\
\hline & 44.82 & $\mathrm{bc}$ & 44.50 & $\mathrm{bc}$ & 43.55 & $\mathrm{~cd}$ & 42.15 & fg & 40.27 & $\mathrm{ij}$ & 38.33 & $\mathrm{kl}$ & 42.27 & $\mathrm{C}$ \\
\hline $75 \% \mathrm{~F}$ & 42.99 & de & 42.49 & ef & 41.41 & gh & 39.25 & $\mathrm{jk}$ & 37.13 & $\mathrm{mn}$ & 34.91 & $\mathrm{n}$ & 39.70 & $\mathrm{D}$ \\
\hline $50 \% \mathrm{~F}$ & 38.77 & $\mathrm{kl}$ & 38.12 & $\operatorname{lm}$ & 36.71 & $\mathrm{mn}$ & 34.48 & $\mathrm{n}$ & 31.11 & o & 28.56 & o & 34.62 & $\mathrm{E}$ \\
\hline $100 \% F+M$ & 47.40 & $\mathrm{a}$ & 47.31 & $\mathrm{a}$ & 46.80 & $\mathrm{a}$ & 46.15 & $a b$ & 45.18 & $\mathrm{bc}$ & 44.04 & $\mathrm{bc}$ & 46.15 & A \\
\hline $75 \% F+M$ & 45.92 & $a b$ & 45.74 & $\mathrm{bc}$ & 44.88 & $\mathrm{bc}$ & 43.84 & $\mathrm{~cd}$ & 42.64 & ef & 40.69 & hi & 43.95 & B \\
\hline $50 \% \mathbf{F}+\mathbf{M}$ & 43.73 & $\mathrm{~cd}$ & 43.36 & de & 42.33 & $\mathrm{fg}$ & 40.85 & hi & 38.78 & $\mathrm{kl}$ & 36.66 & $\mathrm{mn}$ & 40.95 & $\mathrm{D}$ \\
\hline \multirow[t]{2}{*}{ Mean } & 43.94 & A & 43.59 & A & 42.61 & B & 41.12 & $\mathrm{C}$ & 39.19 & $\mathrm{D}$ & 37.20 & $\mathrm{E}$ & & \\
\hline & \multicolumn{14}{|c|}{$2019 / 2020$ season } \\
\hline $100 \%$ F & 41.55 & $\mathrm{~cd}$ & 41.21 & $\mathrm{~cd}$ & 40.22 & de & 38.70 & fg & 36.83 & $\mathrm{jk}$ & 34.77 & no & 38.88 & $\mathrm{C}$ \\
\hline $75 \% \mathrm{~F}$ & 39.72 & ef & 39.21 & ef & 38.05 & hi & 35.68 & $\operatorname{lm}$ & 33.64 & op & 31.54 & $\mathrm{p}$ & 36.31 & $\mathrm{D}$ \\
\hline $50 \%$ F & 36.25 & $\mathrm{kl}$ & 35.37 & $\operatorname{lm}$ & 33.80 & op & 31.25 & $\mathrm{p}$ & 27.51 & $q$ & 25.04 & $q$ & 31.54 & $\mathrm{E}$ \\
\hline $100 \% F+M$ & 45.57 & $\mathrm{a}$ & 44.41 & $\mathrm{a}$ & 43.91 & $a b$ & 43.24 & $a b$ & 41.68 & $\mathrm{~cd}$ & 40.64 & de & 43.24 & A \\
\hline $75 \% F+M$ & 43.05 & $a b$ & 42.26 & $\mathrm{~cd}$ & 41.85 & $\mathrm{~cd}$ & 40.89 & de & 39.08 & fg & 37.14 & $\mathrm{ij}$ & 40.71 & B \\
\hline $50 \% \mathbf{F}+\mathbf{M}$ & 40.92 & $\mathrm{~cd}$ & 40.53 & de & 39.21 & ef & 37.95 & hi & 35.11 & $\mathrm{mn}$ & 32.88 & $\mathrm{p}$ & 37.77 & $\mathrm{C}$ \\
\hline Mean & 41.18 & A & 40.50 & $\mathrm{AB}$ & 39.51 & B & 37.95 & $\mathrm{C}$ & 35.64 & $\mathrm{D}$ & 33.67 & $\mathrm{E}$ & & \\
\hline
\end{tabular}

Means followed in same column by similar letters are not statistically different at 0.05 level according to Tukey test. $\mathrm{F}=$ mineral fertilizer of NPK, $\mathrm{M}=$ magnetic iron

\subsubsection{Color (Hue angle)}

Changes in hue angle values of cucumber fruits are good indicator of senescence. Data in Table 11 indicate that the hue angle $\left(h^{\circ}\right)$ values of cucumber fruits significantly decreased as the storage turned to slight yellow as the storage period prolonged.

Table 11: Effect of mineral fertilizer rates and magnetic iron on hue angle $\left(\mathrm{h}^{\circ}\right)$ of cucumber fruits during cold storage $\left(10^{\circ} \mathrm{C}\right)$ plus shelf life $\left(15^{\circ} \mathrm{C}\right)$ in both seasons

\begin{tabular}{|c|c|c|c|c|c|c|c|c|c|c|c|c|c|c|}
\hline \multirow{4}{*}{$\begin{array}{l}\text { Treatments } \\
100 \% \text { F }\end{array}$} & \multicolumn{14}{|c|}{ Storage period (days) } \\
\hline & \multicolumn{14}{|c|}{ 2018/2019 season } \\
\hline & \multicolumn{2}{|l|}{$\mathbf{0}$} & \multicolumn{2}{|c|}{$\mathbf{0}+\mathbf{2}$} & \multicolumn{2}{|c|}{$4+2$} & \multicolumn{2}{|c|}{$8+2$} & \multicolumn{2}{|c|}{$12+2$} & \multicolumn{2}{|c|}{$16+2$} & \multicolumn{2}{|c|}{ Mean } \\
\hline & 119.7 & ef & 117.2 & hi & 115.1 & $\mathrm{jk}$ & 111.1 & o & 107.8 & $q$ & 103.6 & $\mathrm{~s}$ & 112.4 & $\mathrm{C}$ \\
\hline $75 \% \mathrm{~F}$ & 117.7 & gh & 115.3 & $\mathrm{jk}$ & 112.8 & $\mathrm{mn}$ & 107.8 & $\mathrm{pq}$ & 103.7 & $\mathrm{~s}$ & 98.9 & $\mathrm{t}$ & 109.4 & $\mathrm{D}$ \\
\hline $50 \% \mathrm{~F}$ & 115.1 & $\mathrm{jk}$ & 112.2 & no & 109.5 & $\mathrm{p}$ & 104.2 & rs & 99.5 & $\mathrm{t}$ & 94.1 & $\mathrm{u}$ & 105.8 & $\mathrm{E}$ \\
\hline $100 \% F+M$ & 128.0 & $\mathrm{a}$ & 125.2 & $a b$ & 124.1 & $\mathrm{bc}$ & 123.4 & $\mathrm{bc}$ & 122.1 & $\mathrm{~cd}$ & 120.8 & de & 124.0 & A \\
\hline $75 \% \mathrm{~F}+\mathrm{M}$ & 126.8 & $\mathrm{ab}$ & 124.0 & bc & 122.8 & $\mathrm{~cd}$ & 121.3 & $\mathrm{~cd}$ & 119.4 & ef & 117.4 & hi & 122.0 & B \\
\hline $50 \%$ F + M & 118.9 & fg & 116.2 & $\mathrm{ij}$ & 113.9 & $\operatorname{lm}$ & 110.1 & op & 105.6 & $\mathrm{r}$ & 100.7 & st & 110.9 & $\mathrm{CD}$ \\
\hline \multirow[t]{2}{*}{ Mean } & 121.0 & A & 118.4 & B & 116.4 & $\mathrm{C}$ & 113.0 & $\mathrm{D}$ & 109.7 & $\mathrm{E}$ & 105.9 & $\mathrm{~F}$ & & \\
\hline & \multicolumn{14}{|c|}{$2019 / 2020$ season } \\
\hline $100 \% \mathrm{~F}$ & 116.1 & ef & 113.8 & gh & 111.8 & hi & 107.9 & $\operatorname{lm}$ & 104.4 & $\mathrm{n}$ & 100.3 & op & 109.1 & B \\
\hline $75 \% \mathrm{~F}$ & 113.8 & gh & 111.7 & hi & 109.5 & $\mathrm{jk}$ & 104.8 & $\mathrm{n}$ & 100.2 & op & 95.4 & $\mathrm{qr}$ & 105.9 & $\mathrm{C}$ \\
\hline $50 \% \mathrm{~F}$ & 111.4 & $\mathrm{jk}$ & 108.5 & $\mathrm{kl}$ & 106.0 & $\operatorname{lm}$ & 101.1 & 21 & 96.0 & $\mathrm{qr}$ & 90.5 & $\mathrm{~s}$ & 102.2 & $\mathrm{D}$ \\
\hline $100 \% F+M$ & 126.3 & $\mathrm{a}$ & 122.1 & $\mathrm{bc}$ & 121.2 & $\mathrm{bc}$ & 119.8 & $\mathrm{~cd}$ & 118.4 & $\mathrm{~cd}$ & 116.9 & de & 120.8 & A \\
\hline $75 \% F+M$ & 124.7 & $\mathrm{ab}$ & 120.9 & $\mathrm{bc}$ & 119.7 & $\mathrm{~cd}$ & 117.5 & de & 115.5 & ef & 113.4 & $\mathrm{ij}$ & 118.6 & A \\
\hline $50 \% \mathbf{F}+\mathbf{M}$ & 115.1 & fg & 113.5 & gh & 110.4 & $\mathrm{jk}$ & 106.4 & $\operatorname{lm}$ & 101.6 & op & 96.7 & $\mathrm{qr}$ & 107.3 & $\mathrm{BC}$ \\
\hline Mean & 117.9 & A & 115.1 & B & 113.1 & $\mathrm{C}$ & 109.6 & $\mathrm{D}$ & 106.0 & $\mathrm{E}$ & 102.2 & F & & \\
\hline
\end{tabular}

Means followed in same column by similar letters are not statistically different at 0.05 level according to Tukey test. $\mathrm{F}=$ mineral fertilizer of NPK, $\mathrm{M}=$ magnetic iron 
These results were true in the two seasons and in agreement with Rageh and Abou El-wafa (2017) and Saad (2019). These results may be attributed to a gradual destruction by chlorophylls activity and transformation of chloroplast to chromoplast (Dong et al., 2004).

Concerning the effect of pre-harvest treatments, data showed that cucumber fruits obtained from plants treated with $100 \%$ or $75 \%$ of mineral fertilizer with adding magnetic iron were the most effective treatments in reducing the loss of hue angle value indicating that fruits retained more green color during storage plus shelf life. While the lowest hue angle values were detected in those obtained from $50 \%$ of mineral fertilizer without magnetic iron indicating that fruits had less green color. Cucumber fruits obtained from plants treated with $100 \%$ of mineral fertilizer without magnetic iron or $50 \%$ of mineral fertilizer with adding magnetic iron were less effective in maintaining the green color during storage plus the shelf life. These results were true in the two seasons. Magnetic iron treatments might help in improving fruit quality due to the improvement of vegetative growth parameters of cucumber plants in response to application of magnetic iron which may result in improving quality of cucumber fruit and total green color reading (SPAD) compared to non-treated plants (El-Zawily et al., 2018).

\subsubsection{Firmness}

Data in Table 12 revel that significant reduction in fruit firmness had occurred by prolongation of storage period plus shelf life. These results are in agreement with those obtained by Shehata et al. (2018) and Saad (2019) on cucumber and may be due to gradual breakdown of protopectin to water soluble lower molecular weight fractions leading to the increase in the rate of fruit softening (Wills et al., 1998).

Table 12: Effect of mineral fertilizer rates and magnetic iron on firmness $\left(\mathrm{kg} / \mathrm{cm}^{2}\right)$ of cucumber fruits during cold storage $\left(10^{\circ} \mathrm{C}\right)$ plus shelf life $\left(15^{\circ} \mathrm{C}\right)$ in both seasons

\begin{tabular}{|c|c|c|c|c|c|c|c|c|c|c|c|c|c|c|}
\hline \multirow{4}{*}{$\begin{array}{l}\text { Treatments } \\
100 \% \text { F }\end{array}$} & \multicolumn{14}{|c|}{ Storage period (days) } \\
\hline & \multicolumn{14}{|c|}{ 2018/2019 season } \\
\hline & \multicolumn{2}{|c|}{$\mathbf{0}$} & \multicolumn{2}{|c|}{$0+2$} & \multicolumn{2}{|c|}{$4+2$} & \multicolumn{2}{|c|}{$8+2$} & \multicolumn{2}{|c|}{$12+2$} & \multicolumn{2}{|c|}{$16+2$} & \multicolumn{2}{|c|}{ Mean } \\
\hline & 4.03 & ef & 3.57 & $\mathrm{ij}$ & 3.03 & $\mathrm{jk}$ & 2.43 & op & 1.97 & rs & 1.60 & st & 2.77 & $\mathrm{C}$ \\
\hline $75 \% \mathrm{~F}$ & 3.83 & gh & 3.40 & $\mathrm{jk}$ & 2.80 & $\mathrm{mn}$ & 2.10 & $\mathrm{qr}$ & 1.63 & st & 1.37 & uv & 2.52 & $\mathrm{DE}$ \\
\hline $50 \% \mathrm{~F}$ & 3.73 & $\mathrm{~h}$ & 3.23 & $\mathrm{kl}$ & 2.67 & no & 1.93 & rs & 1.53 & tu & 1.20 & $\mathrm{v}$ & 2.38 & $\mathrm{E}$ \\
\hline $100 \% F+M$ & 5.63 & $\mathrm{a}$ & 5.43 & a & 5.10 & $\mathrm{ab}$ & 4.73 & $\mathrm{bc}$ & 4.30 & de & 3.90 & ef & 4.85 & A \\
\hline $75 \% \mathrm{~F}+\mathrm{M}$ & 5.43 & $\mathrm{a}$ & 5.27 & $a b$ & 4.80 & $\mathrm{bc}$ & 4.23 & de & 3.63 & $\mathrm{ij}$ & 3.17 & $\mathrm{kl}$ & 4.42 & B \\
\hline $50 \% \mathbf{F}+\mathbf{M}$ & 3.90 & ef & 3.43 & $\mathrm{jk}$ & 2.87 & $\mathrm{mn}$ & 2.30 & $\mathrm{pq}$ & 1.77 & $\mathrm{~s}$ & 1.47 & tu & 2.62 & $\mathrm{CD}$ \\
\hline \multirow[t]{2}{*}{ Mean } & 4.43 & A & 4.06 & B & 3.54 & $\mathrm{C}$ & 2.96 & $\mathrm{D}$ & 2.47 & $\mathrm{E}$ & 2.12 & $\mathrm{~F}$ & & \\
\hline & \multicolumn{14}{|c|}{$2019 / 2020$ season } \\
\hline $100 \%$ F & 3.83 & fg & 3.40 & $\mathrm{ij}$ & 2.90 & $\operatorname{lm}$ & 2.33 & op & 1.90 & rs & 1.47 & tu & 2.64 & $\mathrm{C}$ \\
\hline $75 \% \mathrm{~F}$ & 3.70 & gh & 3.23 & $\mathrm{kl}$ & 2.73 & $\mathrm{mn}$ & 2.07 & $\mathrm{qr}$ & 1.60 & tu & 1.20 & $\mathrm{u}$ & 2.42 & $\mathrm{DE}$ \\
\hline $50 \%$ F & 3.57 & hi & 3.13 & 1 & 2.57 & no & 1.90 & rs & 1.47 & tu & 1.10 & $\mathrm{u}$ & 2.29 & $\mathrm{E}$ \\
\hline $100 \% F+M$ & 5.43 & $\mathrm{a}$ & 5.20 & $a b$ & 4.87 & $\mathrm{bc}$ & 4.47 & $\mathrm{~cd}$ & 4.10 & de & 3.80 & $\mathrm{fg}$ & 4.64 & A \\
\hline $75 \% \mathbf{F}+M$ & 5.27 & gh & 5.10 & $a b$ & 4.50 & $\mathrm{~cd}$ & 4.03 & ef & 3.53 & hi & 3.10 & $\operatorname{lm}$ & 4.26 & B \\
\hline $50 \% F+M$ & 3.73 & 6 & 3.30 & $\mathrm{jk}$ & 2.77 & $\mathrm{mn}$ & 2.23 & $\mathrm{pq}$ & 1.73 & $\mathrm{t}$ & 1.37 & tu & 2.52 & $\mathrm{CD}$ \\
\hline Mean & 4.26 & A & 3.89 & B & 3.39 & $\mathrm{C}$ & 2.84 & $\mathrm{D}$ & 2.39 & E & 2.01 & $\mathrm{~F}$ & & \\
\hline
\end{tabular}

Means followed in same column by similar letters are not statistically different at 0.05 level according to Tukey test. $\mathrm{F}=$ mineral fertilizer of NPK, $\mathrm{M}=$ magnetic iron

Regarding the effect of pre-harvest treatments, data showed that cucumber fruits obtained from plants treated with $100 \%$ or $75 \%$ of mineral fertilizer with adding magnetic iron had significantly greater fruit firmness as compared with other treatments during storage plus shelf life, however, cucumber fruits obtained from plants treated with $100 \%$ or $75 \%$ of mineral fertilizer with adding magnetic iron were the most effective treatments in reducing the loss of fruit firmness during storage plus shelf life with significant differences between them. The highest losses of fruit firmness were found in fruits obtained from $75 \%$ or $50 \%$ of mineral fertilizer without magnetic iron treatments. These 
results may be due to the beneficial effect of magnetic iron treatments might help in improving fruit quality due to the improvement of vegetative growth parameters of cucumber plants in response to application of magnetic iron which may result in improving fruit firmness of cucumber compared to non -treated plants (El-Zawily et al., 2018).

The interaction between pre-harvest treatments and storage period was significant in the two seasons. After 16 days of storage at $10{ }^{\circ} \mathrm{C}+2$ days at $15^{\circ} \mathrm{C}$ as a shelf life, data revealed that cucumber fruit from plants treated with $100 \%$ or $75 \%$ of mineral fertilizer with adding magnetic iron had significantly higher fruit firmness as compared with the other treatments in the two seasons.

\subsubsection{Total soluble solids percentage (TSS)}

Data in Table 13 indicate that TSS \% of cucumber fruits decreased significantly with the prolongation of storage period plus shelf life. These results are in agreement with those obtained by Shehata et al. (2009) and Shehata et al. (2018) on cucumber fruits. The hydrolysis of fruit starch is completed, no further increase in TSS\% could be detected and subsequently, a decline in this parameter predictable since sugars along with other organic acids is primary substrates used for respiration (Gerasopoulos and Drogoudi, 2005).

Concerning the effect of pre-harvest treatments, data revealed that cucumber fruits obtained from plants treated with $100 \%$ of mineral fertilizer with adding magnetic iron was the most effective treatment in maintaining TSS $\%$ followed by $75 \%$ of mineral fertilizer with adding magnetic iron or 100 $\%$ of mineral fertilizer without magnetic iron with no significant differences between them, while the lowest ones in this concern were recorded for fruits obtained from $50 \%$ of mineral fertilizer without magnetic iron treatment.

Regarding the interaction between pre-harvest treatments and storage period was significant. After 16 days of storage at $10{ }^{\circ} \mathrm{C}+$ the shelf life, data showed that cucumber fruits obtained from plants treated with $100 \%$ of mineral fertilizer with adding magnetic iron gave the highest values of TSS followed by $75 \%$ of mineral fertilizer with adding magnetic iron or $100 \%$ of mineral fertilizer without magnetic iron with no significant differences between them, while the lowest ones were found in those obtained from $75 \%$ or $50 \%$ of mineral fertilizer without magnetic iron treatments with no significant differences between them.

Table 13: Effect of mineral fertilizer rates and magnetic iron on TSS \% of cucumber fruits during cold storage $\left(10^{\circ} \mathrm{C}\right)$ plus shelf life $\left(15^{\circ} \mathrm{C}\right)$ in both seasons

\begin{tabular}{|c|c|c|c|c|c|c|c|c|c|c|c|c|c|c|}
\hline \multirow{4}{*}{$\begin{array}{l}\text { Treatments } \\
100 \% \text { F }\end{array}$} & \multicolumn{14}{|c|}{ Storage period (days) } \\
\hline & \multicolumn{14}{|c|}{ 2018/2019 season } \\
\hline & \multicolumn{2}{|c|}{$\mathbf{0}$} & \multicolumn{2}{|c|}{$\mathbf{0}+2$} & \multicolumn{2}{|c|}{$4+2$} & \multicolumn{2}{|c|}{$8+2$} & \multicolumn{2}{|c|}{$12+2$} & \multicolumn{2}{|c|}{$16+2$} & \multicolumn{2}{|c|}{ Mean } \\
\hline & 3.33 & $\mathrm{f}$ & 3.17 & $\mathrm{ij}$ & 3.00 & $\mathrm{kl}$ & 2.87 & $\mathrm{~m}$ & 2.70 & op & 2.23 & rs & 2.88 & $\mathrm{BC}$ \\
\hline $75 \% \mathrm{~F}$ & 3.10 & $\mathrm{fg}$ & 2.87 & $\mathrm{ij}$ & 2.67 & 1 & 2.40 & no & 2.03 & rs & 1.53 & $\mathrm{t}$ & 2.43 & $\mathrm{D}$ \\
\hline $50 \% \mathrm{~F}$ & 2.97 & hi & 2.77 & $\mathrm{kl}$ & 2.43 & $\mathrm{mn}$ & 2.07 & $\mathrm{qr}$ & 1.73 & $\mathrm{t}$ & 1.33 & $\mathrm{u}$ & 2.22 & $\mathrm{E}$ \\
\hline $100 \% \mathrm{~F}+\mathrm{M}$ & 3.80 & a & 3.67 & $a b$ & 3.53 & $\mathrm{bc}$ & 3.33 & e & 3.27 & $\mathrm{f}$ & 2.93 & $\mathrm{f}$ & 3.42 & A \\
\hline $75 \% \mathrm{~F}+\mathrm{M}$ & 3.60 & $a b$ & 3.43 & $\mathrm{bc}$ & 3.23 & de & 2.97 & $\mathrm{f}$ & 2.83 & gh & 2.47 & $\mathrm{jk}$ & 3.09 & B \\
\hline $50 \% \mathbf{F}+\mathbf{M}$ & 3.23 & $\mathrm{fg}$ & 3.07 & $\mathrm{ij}$ & 2.87 & 1 & 2.60 & $\mathrm{mn}$ & 2.40 & $\mathrm{pq}$ & 2.07 & $\mathrm{~s}$ & 2.71 & $\mathrm{C}$ \\
\hline \multirow[t]{2}{*}{ Mean } & 3.34 & $\mathrm{~A}$ & 3.16 & B & 2.96 & $\mathrm{C}$ & 2.71 & $\mathrm{D}$ & 2.49 & $\mathrm{E}$ & 2.09 & $\mathrm{~F}$ & & \\
\hline & \multicolumn{14}{|c|}{$2019 / 2020$ season } \\
\hline $100 \%$ F & 2.90 & gh & 2.70 & $\mathrm{ij}$ & 2.47 & $\mathrm{mn}$ & 2.33 & o & 2.17 & $\mathrm{pq}$ & 1.73 & st & 2.38 & $\mathrm{BC}$ \\
\hline $75 \% \mathrm{~F}$ & 2.63 & hi & 2.37 & $\mathrm{kl}$ & 2.10 & $\mathrm{n}$ & 1.87 & op & 1.57 & rs & 1.13 & $\mathrm{v}$ & 1.94 & $\mathrm{DE}$ \\
\hline $50 \%$ F & 2.50 & $\mathrm{ij}$ & 2.23 & $\mathrm{mn}$ & 1.87 & o & 1.53 & $\mathrm{qr}$ & 1.20 & uv & 0.90 & $\mathrm{w}$ & 1.71 & $\mathrm{E}$ \\
\hline $100 \% \mathrm{~F}+\mathrm{M}$ & 3.50 & $\mathrm{a}$ & 3.37 & $a b$ & 3.20 & $\mathrm{~cd}$ & 3.03 & ef & 2.90 & g & 2.67 & gh & 3.11 & A \\
\hline $75 \% F+M$ & 3.20 & $\mathrm{ab}$ & 3.00 & $\mathrm{bc}$ & 2.77 & de & 2.50 & $\mathrm{fg}$ & 2.30 & $\mathrm{ij}$ & 1.97 & $\operatorname{lm}$ & 2.62 & B \\
\hline $50 \% \mathbf{F}+\mathbf{M}$ & 2.77 & gh & 2.60 & $\mathrm{jk}$ & 2.33 & $\mathrm{n}$ & 2.03 & o & 1.73 & $\mathrm{qr}$ & 1.50 & tu & 2.16 & $\mathrm{CD}$ \\
\hline Mean & 2.92 & A & 2.71 & A & 2.46 & B & 2.22 & $\mathrm{C}$ & 1.98 & $\mathrm{D}$ & 1.65 & $\mathrm{E}$ & & \\
\hline
\end{tabular}

Means followed in same column by similar letters are not statistically different at 0.05 level according to Tukey test. $\mathrm{F}=$ mineral fertilizer of NPK, $\mathrm{M}=$ magnetic iron 


\subsubsection{Ascorbic acid}

Data in Table 14 show that ascorbic acid content of cucumber fruit was significantly decreased by the prolongation of storage period plus shelf life. These results are true in the two seasons and in agreement with those obtained by Shehata et al. (2009) and Shehata et al. (2018) on cucumber fruits. This reduction might be due to the higher rate of sugar loss through respiration than water loss through transpiration (Wills et al., 1998).

Concerning the effect of pre-harvest treatments, data revealed that fruits obtained from plants treated with $100 \%$ or $75 \%$ of mineral fertilizer with adding magnetic iron were higher in fruit ascorbic acid with significant differences between them followed by fruits obtained from $100 \%$ of mineral fertilizer without magnetic iron or $50 \%$ of mineral fertilizer with adding magnetic iron with no significant differences between them, while $75 \%$ of mineral fertilizer without magnetic iron was less effective in this concern. The lowest value of ascorbic acid content was obtained from applying $50 \%$ of mineral fertilizer without magnetic iron. These results were true in the two seasons.

In general, the interaction between pre-harvest treatments and storage period was significant, however, cucumber fruits obtained from plants treated with $100 \%$ or $75 \%$ of mineral fertilizer with adding magnetic iron were the best in maintaining ascorbic acid content at the end of storage period plus the shelf life ( 16 days of storage at $10^{\circ} \mathrm{C}+2$ days at $15^{\circ} \mathrm{C}$ ), while the lowest ones was found in those obtained from $50 \%$ of mineral fertilizer without magnetic iron treatment.

Table 14: Effect of mineral fertilizer rates and magnetic iron on ascorbic acid content (mg/100 g FW) of cucumber fruits during cold storage $\left(10^{\circ} \mathrm{C}\right)$ plus shelf life $\quad\left(15^{\circ} \mathrm{C}\right)$ in both seasons

\begin{tabular}{|c|c|c|c|c|c|c|c|c|c|c|c|c|c|c|}
\hline \multirow{4}{*}{$\begin{array}{l}\text { Treatments } \\
100 \% \text { F }\end{array}$} & \multicolumn{14}{|c|}{ Storage period (days) } \\
\hline & \multicolumn{14}{|c|}{$2018 / 2019$ season } \\
\hline & \multicolumn{2}{|c|}{$\mathbf{0}$} & \multicolumn{2}{|c|}{$0+2$} & \multicolumn{2}{|c|}{$4+2$} & \multicolumn{2}{|c|}{$8+2$} & \multicolumn{2}{|c|}{$12+2$} & \multicolumn{2}{|c|}{$16+2$} & \multicolumn{2}{|c|}{ Mean } \\
\hline & 2.90 & $\mathrm{~cd}$ & 2.85 & de & 2.80 & fg & 2.77 & gh & 2.72 & hi & 2.67 & $\operatorname{lm}$ & 2.78 & $\mathrm{C}$ \\
\hline $75 \% \mathrm{~F}$ & 2.87 & ef & 2.84 & gh & 2.79 & hi & 2.75 & $\mathrm{k}$ & 2.67 & $\mathrm{mn}$ & 2.62 & op & 2.76 & $\mathrm{D}$ \\
\hline $50 \% \mathrm{~F}$ & 2.85 & fg & 2.80 & hi & 2.75 & $\mathrm{jk}$ & 2.68 & $\mathrm{mn}$ & 2.63 & o & 2.56 & $\mathrm{p}$ & 2.71 & $\mathrm{E}$ \\
\hline $100 \% F+M$ & 2.99 & $\mathrm{a}$ & 2.97 & $\mathrm{a}$ & 2.95 & $a b$ & 2.92 & $\mathrm{~cd}$ & 2.89 & $\mathrm{~cd}$ & 2.88 & fg & 2.93 & A \\
\hline $75 \% \mathrm{~F}+\mathrm{M}$ & 2.98 & $a b$ & 2.96 & $\mathrm{bc}$ & 2.93 & de & 2.90 & fg & 2.85 & gh & 2.82 & $\mathrm{jk}$ & 2.91 & B \\
\hline $50 \% \mathbf{F}+\mathbf{M}$ & 2.88 & de & 2.84 & ef & 2.79 & gh & 2.73 & $\mathrm{ij}$ & 2.70 & $\mathrm{k}$ & 2.65 & $\mathrm{mn}$ & 2.77 & $\mathrm{CD}$ \\
\hline \multirow[t]{2}{*}{ Mean } & 2.91 & A & 2.87 & B & 2.84 & $\mathrm{C}$ & 2.79 & $\mathrm{D}$ & 2.74 & $\mathrm{E}$ & 2.70 & $\mathrm{~F}$ & & \\
\hline & \multicolumn{14}{|c|}{$2019 / 2020$ season } \\
\hline $100 \%$ F & 2.83 & de & 2.79 & ef & 2.75 & $\mathrm{ij}$ & 2.70 & $\mathrm{jk}$ & 2.66 & $\mathrm{kl}$ & 2.60 & no & 2.72 & $\mathrm{C}$ \\
\hline $75 \% \mathrm{~F}$ & 2.81 & fg & 2.78 & $\mathrm{ij}$ & 2.73 & $\operatorname{lm}$ & 2.68 & $\operatorname{lm}$ & 2.62 & op & 2.56 & $\mathrm{pq}$ & 2.70 & $\mathrm{D}$ \\
\hline $50 \%$ F & 2.79 & hi & 2.75 & $\mathrm{kl}$ & 2.70 & $\operatorname{lm}$ & 2.64 & op & 2.57 & $\mathrm{pq}$ & 2.51 & $\mathrm{q}$ & 2.66 & $\mathrm{E}$ \\
\hline $100 \% F+M$ & 2.96 & $\mathrm{a}$ & 2.93 & $\mathrm{a}$ & 2.91 & 16 & 2.87 & $\mathrm{~cd}$ & 2.84 & de & 2.83 & fg & 2.89 & A \\
\hline $75 \% \mathrm{~F}+\mathrm{M}$ & 2.94 & $\mathrm{bc}$ & 2.92 & $\mathrm{~cd}$ & 2.89 & ef & 2.85 & hi & 2.80 & $\mathrm{kl}$ & 2.77 & $\mathrm{mn}$ & 2.86 & B \\
\hline $50 \% \mathbf{F}+\mathbf{M}$ & 2.83 & ef & 2.78 & gh & 2.74 & $\mathrm{jk}$ & 2.69 & $\mathrm{mn}$ & 2.64 & no & 2.59 & op & 2.71 & $\mathrm{CD}$ \\
\hline Mean & 2.86 & A & 2.83 & B & 2.79 & $\mathrm{C}$ & 2.74 & $\mathrm{D}$ & 2.69 & E & 2.64 & $\mathrm{~F}$ & & \\
\hline
\end{tabular}

Means followed in same column by similar letters are not statistically different at 0.05 level according to Tukey test.

$\mathrm{F}=$ mineral fertilizer of NPK, $\mathrm{M}=$ magnetic iron

\section{Conclusion}

All vegetative growth properties, nutritional status of plants, yield and properties of cucumber fruits were improved by increasing mineral fertilizer rate to $100 \%$. The plants treated with magnetic iron led to increase the growth, NPK content of plants, yield and properties of cucumber fruits compared to untreated plants. The highest yield was produced by using $100 \%$ mineral fertilizer with adding magnetic iron. Noteworthy, application of $75 \%$ mineral fertilizers with adding magnetic iron had achieved yield and fruit quality higher than using $100 \%$ mineral fertilizer without magnetic iron.

Adding magnetic iron with different mineral fertilizer rates achieved superiority in nutrient use efficiency compared to non-adding magnetic iron. The highest nutrient use efficiency was true using 
magnetic iron with $50 \%$ mineral fertilizer, which contributes to reducing environmental pollution and greenhouse gas emissions.

The treatment of $100 \%$ mineral fertilizer with adding magnetic iron was the most effective treatment in maintaining fruit quality, improving storability of cucumber fruits and had a good appearance till 16 days of storage at $10^{\circ} \mathrm{C}$ plus two days at $15^{\circ} \mathrm{C}$ as a shelf life.

\section{Acknowledgement}

This work has been supported by Department of Postharvest and Handling of Vegetable Crops, Horticulture Research Institute - Central Laboratory for Agricultural Climate (CLAC) - Central Lab of Organic Agriculture (CLOA), Agriculture Research Center, Giza, Egypt.

\section{References}

Ali, T.B., S.E. Khalil and A.M. Khalil, 2011.Magnetic treatments of Capsicum annuum L. grown under saline irrigation conditions. J. Appl. Sci. Res., 7(11): 1558-1568.

A.O.A.C., 2000.Association of Official Analytical Chemists. Washington DC. International $17^{\text {th }}$ Edition, Revision I, 490-510.

Atrees, A.S.H. and O.O. Mohamed, 2014. Impact of foliar spraying with iron and magnesium on growth, yield, chemical constituents and storability of broccoli.Annals of Agric. Sci. Moshtohor, 52(2): 261- 272.

Dong, H., L. Cheng, J. Tan, K. Zheng and Y. Jiang, 2004. Effects of chitosan coating on quality and shelf-life of peeled litchi fruit. J. Food Engineering, 64(3): 355-358.

Egypt's first Biennial Update Report, 2018. Published by Ministry of Environment, Egyptian Environmental Affairs Agency, Website: www.eeaa.gov.eg.

Eifediyi, E.K. and S.U. Remison, 2010. Growth and yield of cucumber (Cucumis sativum L.) as influenced by farmyard manure and inorganic fertilizer. J. Plant Breeding and Crop Sci., 2(7): 216-220.

El-Eslamboly, A.A.S.A. and M.A.S. Abdel-Wahab, 2014. Grafting salinity tolerant rootstocks and magnetic iron treatments for cantaloupe production under conditions of high salinity soil and irrigation water. Middle East J. Agric. Res., 3(3): 677-693.

El-Gizawy, A.M., M.E. Ragab, N.A.S. Helal, A. El-Satar and I.H. Osman, 2016. Effect of magnetic field treatments on germination of true potato seeds, seedlings growth and potato tubers characteristics. Middle East J. Agric. Res., 5(1): 1-8.

El-Hifny, I.M.M., M.E. Ramadan, I.I. El-Oksh and M.M. Soliman, 2008. Effect of some cultural practices on cauliflower tolerance to salinity under RasSuder conditions. J. Biol. Chem. \& Environ. Sci., 3(1): 899-913.

El-Zawily, A.I., M.B.I. El-Sawy, E.M.H. EL-Semellawy and R.Sh.A. Abd-EL-Ghaffar, 2018. Effect of magnetization and nano potassium particles on growth, yield and fruit quality of cucumber under plastic house conditions. J. Product. and Dev., 23(3): 627- 652.

Esitken, A. and M. Turan, 2004. Alternating magnetic field effects on yield and plant nutrient element composition of strawberry (Fragaria $x$ ananassa cv. Camarosa). Acta Agriculturae Scandinavica, 54(3): 135-139.

FAO, 2008. Guide to laboratory establishment for plant nutrient analysis. Fertilizer and Plant Nutrition Bulletin 19.

Farag, A.A. and Shaimaa H. Abd-Elrahman, 2016. Greenhouse gas emission from cauliflower grown under different nitrogen rates and mulches. Int. J. Plant \& Soil Sci., 9(1): 1-10.

Feleafel, M.N., Z.M. Mirdad and A.S. Hassan, 2014. Effect of NPK fertigation rate and starter fertilizer on the growth and yield of cucumber grown in greenhouse. J. Agri. Sci., 6(9): 81-92.

Gerasopoulos, D. and P.D. Drogoudi, 2005. Summer- pruning and preharvest calcium chloride sprays affect storability and low temperature breakdown incidence in kiwifruit. Post-Harvest Biol. Techno., 36: 303-308.

Ismail, A.E., S.S. Soliman, E.M. Abd El-Moniem, M.S. Awaad and A.A. Rashad, 2010. Effect of magnetic iron ore, metal compound fertilizer and bio-NK in controlling root-knot nematode of grapevine in a newly reclaimed area of Egypt. Pak. J. Nematol., 28(2): 307-328. 
Jilani, M.S., A. Bakar, K. Waseem and M. Kiran, 2009. Effect of different levels of NPK on the growth and yield of cucumber (Cucumis sativus) under the plastic tunnel. J. Agric. Soc. Sci., 5(3): 99101.

Jisha Chand, A.R., 2014. Nutrient use efficiency and economics of salad cucumber using drip fertigation in Naturally Ventilated Oolyhouse. IOSR J. Agric. Vet. Sci., 7: 22-25.

Mahdi, S.S., G.I. Hassan, S.A. Samoon, H.A. Rather, S.A. Dar and B. Zehra, 2010. Bio-fertilizers inorganic agriculture. J. Phytol., 2(10): 42-54.

Mansour, E.R., 2007.Effect of some culture practices on cauliflower tolerance to salinity under RasSuder conditions. M.Sc. Thesis, Fac. Agric., Ain Shams Univ., Egypt.

Marschner, H., 1995. Mineral nutrition of higher plants ( $2^{\text {nd }}$ ed., p. 864). Acad Press Limited, Text Book.

McGuire, R.G., 1992. Reporting of objective color measurements. Hort. Science, 27(12): 1254-1255.

Ministry of Agriculture and Land Reclamation (EAS), Economic Affairs Sector 2017. The Indicators Agriculture Statistics.

Mohamed, H.M., F.A. Al- kamar and A.A.M. Abd-Elall, 2013. Effect of magnetite and some biofertilizer application on growth and yield of Valencia Orange trees under El -Bustan condition. Nature and Science, 11(6): 46- 61.

Naik, H.P., P.C. Mali, V.D. Kapse, K.P. Vaidya, R.V. Dhopavkar, N.A. Meshram and S.S. More, 2019. Response of $\mathrm{F}_{1}$ hybrids of cucumber (Cucumis sativus $\mathrm{L}$.) to different levels of fertilizers under Konkan agro climatic condition. The Pharma Innovation Journal, 8(12): 429-430.

Podlesny, J., S. Pietruszewski and A. Podlesna, 2005. Influence of magnetic stimulation of seeds on the formation of morphological features and yielding of the pea. Int. Agrophysics, 19(1): 61-68.

Qu, F., J.J. Jiang, J.W. Xu, T. Liu and X.H. Hu, 2019. Drip irrigation and fertilization improve yield, uptake of nitrogen and water-nitrogen use efficiency in cucumbers grown in substrate bags. Plant, Soil Environ., 65(6): 328-335.

Rageh, M.A. and S.M. Abou-Elwafa, 2017. Effect of jasmin oil and active dry yeast as a preharvest spray on alleviating chilling injury in cucumber fruits during cold storage. Middel East J. Agric. Res., 6(4): 1144-1154.

Rezaiiasl, A., A. Ghasemnezhad and S. Shahabi, 2012. Study the response of cucumber plant to different magnetic fields. Journal of Advanced Laboratory Research in Biology, 3(1): $42-46$.

Saad, M. EL-M., 2019. Effect of some postharvest treatments on reducing chilling injury of cucumber fruits during cold storage. Annals of Agric. Sci. Moshtohor, 57(2): 455- 468.

Salisbury, F.B. and C.W. Ross, 1991. Plant Physiology. $4^{\text {th }}$ Edition.Wadsworth, Belmont, California. 540.

Shahin, M.M., A.M.A. Mashhour and E.S.E. Abd-Elhady, 2016. Effect of magnetized irrigation water and seeds on some water properties, growth parameter and yield productivity of cucumber plants. Curr. Sci. Int., 5(2): 152-164.

Shehata, S.A., H.A. Hassan, A.A. Tawfik and M.F. Farag, 2016. Improving the productivity and quality of the cucumber crop grown under greenhouse conditions using some stimulants and spraying amino acids. J. Plant Production, Mansoura Univ., 7(4): 385-392.

Shehata, S.A., M. EL-M. Saad, M.A. Saleh and S.A. Atala, 2018. Effect of foliar spray with potassium silicate on growth, yield, quality and storability of cucumber fruits. Annals of Agric. Sci. Moshtohor, 56(2): $385-396$.

Shehata, S.A., M.Y. Hashem and M.M. Attia, 2009. Combined application of hot water and low temperature conditioning reduced chilling injury and maintained quality of cucumber fruits during storage. Annals of Agric. Sci. Moshtohor, 49(3): 27-34.

Shehata, S.A., Y.M. Ahmed, Y.T. Emam and M.A. Azoz, 2012. Influence of some organic and inorganic fertilizers on vegetative growth, yield and yield components of cucumber plants. Res. J. Agric. \& Biol. Sci., 8(2): 108-114.

Singh, M.C., K.G. Singh and J.P. Singh, 2019. Nutrient and water use efficiency of cucumbers grown in soilless media under a naturally ventilated greenhouse. J. Agr. Sci. Tech., 21(2): 193-207.

Simpson, R.J., A. Oberson, R.A. Culvenor, M.H. Ryan, E.J. Veneklaas, H. Lambers, J.P. Lynch, P.R. Ryan, E. Delhaize, F.A. Smith, S.E. Smith, P.R. Harvey and A.E. Richardson, 2011. Strategies and agronomic interventions to improve the phosphorus-use efficiency of farming systems. Plant and Soil, 349: 89-120. 
Snedecor, G.W. and W.G. Cochran, 1980. Statistical methods. Sixth Edition, Iowa state university press, Ames., Iowa, U.S.A.

Taha, B.A., S.E. Khalil and A.M. Khalil, 2011. Magnetic treatments of Capsicum annuum L. grown under saline irrigation conditions. J. Appl. Sci. Res., 7(11): 1558-1568.

Wills, R., B. Mcglasson, D. Graham and D. Joyce, 1998. Postharvest: An introduction to the physiology and handling of fruit, vegetables and ornamentals.Ed.: CAB International, Wallingford, UK. Zagazig J. Agric. Res., 17: 877-882. 